\title{
Paranaguá, Antonina e Curitiba, início do século XIX: reconstituindo espaços e a lógica de sua organização social'
}

\begin{abstract}
Allan Thomas Tadashi Kato ${ }^{2}$
RESUMO: O objetivo desse artigo é desenvolver uma metodologia para caracterizar a espacialização, no início do século XIX, dos moradores arrolados nas décimas urbanas de Paranaguá, Antonina e Curitiba, três vilas do sul da capitania de São Paulo. Apresentamos aqui os problemas enfrentados e decisões tomadas, quase sempre provisórias e arbitrárias. $\bigcirc$ resultado chegou a plantas hipotéticas dos loteamentos e arruamentos urbanos daquelas vilas. A partir de um banco de dados - elaborado principalmente com informações das Listas Nominativas de Habitantes -, foi possível caracterizar os moradores arrolados nos livros de imposto predial de Décima. Espacializando esses dados em plantas temáticas, foi possível perceber onde moravam os grupo sociais, suas escolhas (ou a falta delas), ou seja, perceber seus locais preferenciais, mas não exclusivos, de habitação.

PALAVRAS-CHAVE: organização socioespacial; vizinhança; espaço citadino, reconstituição

ABSTRACT: This paper is to develop a methodology to characterize the spatial distribution in the early nineteenth century, the urban residents enrolled in the Décima of Paranaguá, Antonina and Curitiba, three villages in southern province of São Paulo. Here are the problems faced and decisions made, almost always temporary and arbitrary. The result reached hypothetical plants of subdivisions and urban streets of those towns. From a database - developed mainly with the information Lista Nominativa de Habitantes - it was possible to characterize residents enrolled in the books of property tax Décima. Spatialising thematic data in plants, where they lived was possible to perceive the social group, your choices (or lack thereof), or realize their preferred sites, but not exclusive housing.

KEYWORDS: sociospatial organization, neighborhood, city space, the restoration
\end{abstract}

Povos ordenam seu espaço citadino segundo sua cultura. A compreensão do que entendem por "rua" ajuda a perceber a ideia que diferentes

\begin{abstract}
1. Agradecemos à Capes e ao CNPq pela concessão de bolsas que nos permitiram realizar a dissertação de mestrado. Este artigo é fruto dessa dissertação.

2. Pesquisador do Centro de Documentação e Pesquisa da História dos Domínios Portugueses, séculos XV-XIX (Cedope), da Universidade Federal do Paraná. Mestre em História (UFPR), sob orientação do Prof. Dr. Magnus Roberto de Mello Pereira.E-mail: <atkato@gmail.com>.
\end{abstract}


3. Cf. Magnus Roberto M. Pereira (1999, p. 126).

4. Cf. Beatriz Kushnir (2007, p. 90).

5.Trata-se da chamada Décima urbana de Paranaguá, que está no Livro de Lançamento do imposto de dízimos de Paranaguá (10 nov.1808 a 6 fev. 1857), códice IM V.1 do Acervo do Arquivo da Câmara Municipal de Curitiba. Há cópia digital pertencente ao Cedope, no Departamento de História da Universidade Federal do Paraná.Apesar do marco cronológico 1808 1857, só existe uma Décima de Paranaguá, a de 1808. A primeira transcrição conhecida deste alvará foi publicada no final do século XIX. cf. Brasil (1891a, p.69-73)

6. O termo logradouro, aqui, inclui ruas, travessas, becos, largos etc., além daqueles constantes de seu significado dicionarizado: "lugar, como praças, jardins, hortos, passeios etc., mantidos pelas municipalidades para desfrute da população"; ver Antonio Houaiss (2007).

7. Cf. Ângelo A. Carrara (2003, p. 34). culturas fazem de "cidade". No caso da tradição europeia medieval, percebe-se que a rua era formada anonimamente por um contínuo de fachadas em disputa por acesso ao ar, à água e a mais espaço. Pelo que vimos, assim era a rua referida pela documentação tratada: uma ideia de rua trazida pelos reinóis portugueses, que a reproduziram indefinidamente nos espaços coloniais. Apesar de aparentes diferenças, tanto os tratados renascentistas quanto a atuação das autoridades administrativas - e também a prática quotidiana dos habitantes das cidades ocidentais - confluíram para esse modelo de implantação urbana que tem na rua o seu modelo definidor ${ }^{3}$.

Tendo em mente que relações sociais específicas geram formas distintas de ocupar o chão urbano, propomos um olhar mais detalhado sobre determinadas práticas sociais que são básicas na organização espacial da cidade lusobrasileira, sendo a primeira delas a distribuição socioespacial dos moradores. A questão fundamental daí decorrente é tentar desvendar a maneira como os moradores de nossas vilas e cidades se agrupavam, estabelecendo vizinhanças. Essa "vizinhança" é outra modalidade de "ordem" urbana, cujo foco está na seleção dos "vizinhos apropriados". Então nos perguntamos se, no desenho urbano de Paranaguá, Antonina e Curitiba no início do século XIX, existiriam diferenças que evocassem qualquer tipo de distinção na organização espacial. Caso afirmativo, quais eram, então, as relações entre o local de habitação urbana e a posição social e econômica dos moradores.

Fonte de partida

Em Portugal, a Décima urbana era cobrada desde meados do século $\mathrm{XVII}^{4}$. No Brasil, esse imposto predial foi promulgado em 27 de junho de $1808^{5}$. Essa foi a primeira vez que a Coroa determinou a cobrança de um tributo sobre todas as edificações citadinas no ultramar: um imposto de 10\% sobre o valor de aluguel (real ou estimado) dos imóveis, a ser pago pelos inquilinos ou proprietários moradores de cidades litorâneas, no Brasil e nos outros domínios lusos. Caso o imóvel não estivesse alugado, a Junta do imposto arbitraria o preço. A exceção eram as Santas Casas, pela piedade do seu instituto, e as cidades da Ásia, que estavam isentas devido à "decadência" em que se encontravam.

Os livros de Décima produzidos na comarca de Paranaguá são semelhantes aos de outras regiões do Brasil. Era corrente que, às vezes, os

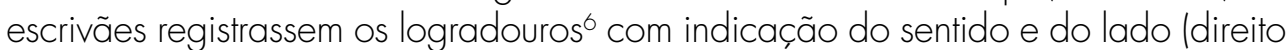
e esquerdo) em que foram arrolados os proprietários. Registravam-se comumente o nome do proprietário e o do chefe da família moradora (mesmo sendo segundo domić́lio), assim como os valores de aluguel e do imposto. Os livros de Décima da capitania de Minas tinham, por exemplo, essas informações? ${ }^{7}$.

Outros dados variavam, pois eram de iniciativa de cada escrivão. Nas cidades do Rio de Janeiro e São Paulo, os escrivães anotaram um número maior 
de informações, como a tipologia (térreo, sobrado e assobradado), e subtipologias (número de lanços, quintal e cozinha) ${ }^{8}$. Nas décimas de Paranaguá, São Paulo e Rio de Janeiro foram indicadas as ruas em que se localizavam os armazéns; e, na Décima de Antonina, a cobertura de palha de parte das casas.

Para as vilas litorâneas da comarca de Paranaguá, foi escriturado um livro - iniciado em 10 de novembro de 1808 - contendo as décimas da jurisdição. No termo de abertura consta que estavam registrados os impostos prediais de Paranaguá (sede da comarca), Antonina, São Francisco, lguape, Guaratuba e Cananeia. No entanto, não encontramos no referido livro as duas últimas localidades. Dele, analisamos as duas primeiras vilas - Paranaguá e Antonina.

Na comarca, a primeira cobrança do imposto a ser instituída foi a de Paranaguá, cujo livro contendo a Décima passou a ser escriturado em 14 de novembro de 1808. No livro parnanguara de Décima, os lançamentos foram organizados por ruas e travessas. Em relação à maioria das vias, o escrivão teve o cuidado de definir o lado da rua (esquerdo ou direito) em que se localizava a casa do morador tributado; e, em relação a algumas ruas, foi anotada a direção (sequência) em que foi feito o arrolamento (rua do Terço indo para o São Francisco, por exemplo). Quase sempre, arrolaram-se separadamente as casas de um lado; depois, as do outro. A numeração das casas, anotadas na margem das páginas, reiniciava a cada novo logradouro. Foram arrolados 294 imóveis distribuídos em onze logradouros.

Em cada anotação de domicílio foram registrados o nome do proprietário, o do inquilino (se havia), a situação do morador com relação à casa (se proprietário, se chefe em casa alugada, emprestada etc.), preço do aluguel anual em réis (às vezes, o valor mensall), assim como os valores dos abatimentos para consertos e o da Décima, como no lançamento a seguir:

\footnotetext{
[Paranaguá]

rua do Terço indo para o São Francisco

Lado esquerdo

Casas próprias do Tenente Coronel Ricardo Carneiro dos Santos alugadas ao Capitão Antonio Jose Alves pela quantia de nove mil e seiscentos por ano vem a sair de cima a quantia de novecentos e sessenta dos quais abatida a de cima para consertos na forma do Regimento vem a décima oitocentos e sessenta e quatro réis com a qual a quantia se sai a margem ... 864\$. Lançada no Livro da Receita, fl. $3^{9}$.
}

Foram relacionados mesmo aqueles imóveis em ruínas ou em construção, sem condições de habitação - 4,4\% dos imóveis -, mas sem imposto, porque não havia valor de aluguel a taxar. A indicação do número de pavimentos (sobrados de um andar e térreos) foi feita no corpo do texto e na margem.

No dia 17 de novembro de 1808, o mesmo escrivão de Paranaguá escriturou o livro de Décima de Antonina ${ }^{10}$. Nesta vila, teve o cuidado de anotar, para algumas casas, a cobertura de palha las demais eram, provavelmente,
8. Cf. Beatriz P. S. Bueno (2005, p. 63); Raquel Glezer (2007, p. 82-86); e Nireu Cavalcanti (2004, p. 259-272).

9. Cf. Décima urbana de Paranaguá,f. 9r.

10. Ver Décima urbana de Antonina, que foi encadernada, como a de Paranaguá no Livro de Lançamento do imposto de dízimos de Paranaguá 
11.Cf.Brasil (1891b, p. 72-73).

12. Modernamente nomeado Livro de Lançamento de dízimo (predial) de Curityba, códice IM V.2 do Acervo do Arquivo da Biblioteca da Câmara Municipal de Curitiba. Assim como no livro de impostos para o litoral, desconhecemos o título original, pois a última encadernação é do final do século XX. O livro de Décima urbana de Curitiba inicia na folha $139 \mathrm{r}$ e termina na $178 \mathrm{v}$.

13. Ver Miguel S. de M. Bandeira (2000); Beatriz P. S. Bueno (2005); Sandro V. Gomes (2004); e Allan T.T. Kato (2004). cobertas com telhas). Às vezes, o escrivão teve o cuidado de definir o lado da rua (esquerdo e direito) em que se localizava o imóvel tributado. A direção em que foram contabilizadas as casas geralmente não foi registrada (com exceção das travessas - para o campo, e para o mar). As 114 casas foram numeradas sequencialmente, sem que se reiniciasse a cada novo logradouro (foram registradas sete ruas ou travessas).

Assim como na cabeça da comarca (e como determinava a lei), em Antonina era registrado o nome do proprietário, o do inquilino (se havia), a situação do morador com relação à casa (se moradia, fechada, alugada etc.), valor do aluguel anual em réis, assim como a taxa da Décima. Também aqui os imóveis sem condição de habitação ou uso - 18\% das casas - foram relacionados, porém sem imposto; mas, diferindo de Paranaguá, não foram anotados sobrados nem armazéns, provavelmente por não existirem.

Em um segundo momento, as cidades do sertão foram incluídas na cobrança. $\bigcirc$ Alvará de 3 de junho de 1809 determinaria a extensão do imposto para todas as aglomerações urbanas no Brasil ${ }^{11}$. A partir de então, os oficiais camarários de Curitiba elaboraram o livro de Décima do município ${ }^{12}$. Dentre aqueles analisados, é o livro onde há menos informações sobre as casas da vila.

Os lançamentos curitibanos foram divididos por onze ruas e mais o pátio e largo da Matriz. O escrivão não teve o cuidado de definir o lado da rua (esquerdo ou direito) em que se localizava a moradia tributada, tampouco foi anotada a direção em que o arrolamento foi feito. Em cada nota registrou-se o nome do proprietário e o do morador (geralmente a mesma pessoa), a situação deste em relação à casa, e valores do aluguel e do imposto. Como nos das outras duas vilas analisadas, os imóveis sem condição de uso - 19,7\% - foram lançados, mas sem atribuição de valor. Registraram-se os sobrados (e suas localizações), porém não houve o mesmo cuidado ao anotar as casas comerciais. A cada novo logradouro, a numeração das casas reiniciava.

É importante dizer que edifícios administrativos e igrejas não foram registrados nos livros de Décima e, portanto, tampouco taxados. $\bigcirc$ alvará não determinava a isenção desses prédios, mas foi o que aconteceu. Já as casas de Câmara que funcionavam em casas alugadas de proprietários privados foram tributadas. No caso especifico de Paranaguá, havia uma casa de fundição de ouro que também não foi arrolada nem taxada na Décima.

Planta-base

A primeira etapa do processo foi a escolha das plantas que serviriam de suporte para a espacialização dos dados arrolados nos livros do imposto de Décima. Quatro pesquisadores ${ }^{13}$ realizaram procedimento semelhante e enfrentaram a mesma dificuldade: não encontraram plantas cadastrais das localidades em estudo para períodos próximos aos das fontes analisadas. Assim, 
- geógrafo português Miguel Bandeira georreferenciou em planta de 1868 os chefes arrolados no Mapa das ruas de Braga, de 1750 14. A historiadora de arquitetura Beatriz Bueno distribuiu em planta cadastral de 1847 os chefes inventariados na Décima paulista de 180915. Já Sandro V. Gomes e este autor espacializaram em plantas cadastrais atuais os chefes registrados na Décima de Antonina $^{16}$ e na de Paranaguá ${ }^{17}$.

Tendo em vista algumas constatações, foi confirmada a conveniência de usarem-se plantas atuais, pois, se observarmos as regiões centrais em plantas cadastrais modernas de Paranaguá, Antonina e Curitiba, é possível perceber uma dada configuração espacial que permite supor, com relativa segurança, que preservam as mesmas características básicas do traçado que essas (então) vilas tinham no início do século XIX.

Isso ocorre por ser o lote urbano um documento inscrito no solo. Seu formato denuncia o modelo (europeu) de ocupação territorial utilizado, cujas características se preservaram, em grande medida, ao longo dos séculos. Assim, excetuando reformas nas ruas - aberturas e alargamentos -, essas cidades mantiveram seus setores históricos relativamente preservados quanto à constituição dos lotes, pelo menos até o início do século XX, mas, em geral, durante todo ele.

Desde que foram definidos os tamanhos dos lotes e construídas as casas em cada lado da rua, os quarteirões mais antigos em geral mantiveram suas características, devido às dificuldades de reurbanização. É essa permanência que permite a utilização das atuais plantas cadastrais como bases para as plantas hipotéticas. De fato, nossas fontes são o loteamento e o arruamento em si, em sua existência material, e as plantas cadastrais são apenas representações modernas disso.

Na sequência, procurou-se confrontar os dados das plantas cadastrais com informações trazidas de documentos de época, tais como plantas, iconografia e descrições. O objetivo era comparar os diferentes discursos sobre o urbano, procurando utilizá-los, da melhor forma possível, na reconstituição espacial das vilas, com especial atenção ao loteamento e ao arruamento urbanos.

Dentre essas fontes, algumas mereceram atenção especial, por indicar a posição dos lotes ou os nomes dos logradouros. A planta de Paranaguá, de 1815, período muito próximo ao ano de nosso interesse, é bastante esclarecedora $^{18}$. Esse desenho nos traz, de modo global, a localização dos quarteirões e áreas até então ocupadas, mas não o loteamento e o arruamento propriamente ditos. Trata-se de excelente indicativo de onde, em anos anteriores, as casas estariam localizadas, o que reforça nossa suspeita quanto à permanência do traçado e do loteamento de Paranaguá.

Já o arruamento de Curitiba está melhor ilustrado em plantas de meados do século XIX. Nelas é possível conhecer a área urbana ocupada e os topônimos de então. A planta de 1857 é assinada por Pierre Taulois, engenheiro francês ${ }^{19}$. Já a planta representativa das décadas de 1830-185020 foi produzida, provavelmente, a partir dessa planta do engenheiro, mas sua autoria e ano
14. Cf. Miguel S.de M. Bandeira (2000, p. 48).

15. Cf. Beatriz P. S. Bueno (2005, p. 60).

16. Cf. Sandro V. Gomes (2004, p. 50).

17. Cf. Allan T. T. Kato (2004, p. 7).

18. Reproduzida em Nestor G. Reis Filho (2001, p. 222).

19. Reproduzida em Irã José T. Dudeque (1985, p. 121).

20. Reproduzida em Paraná (1981, p.19). 
21. Cf. Raquel Glezer (2007, p. 170-171).

22.Trata-se do Plano Agache, 1941-1943.

23. Reproduzida em Paraná (2001).

24. Ibidem.

25. Ver Auguste Saint-Hilaire (1995); e Martim Francisco R. de.Andrada (1882). específico de produção são desconhecidos. Parte do arruamento indicado parece ter, no entanto, algum fundamento, sendo corroborado por outras fontes.

Ainda para Curitiba, plantas do século XX também ajudam a pensar a ocupação urbana assim como o arruamento do período. Comparando-se plantas da passagem e do início do século (1894, 1900, 1904, 1917, 1926), percebemos que, se houve alterações no arruamento e no formato dos quarteirões, elas foram mínimas. Isso devido à dificuldade de impor novo traçado à área da ocupação inicial. Os moradores eram propensos a dificultar as mudanças. Não queriam perder seu espaço - e as dificuldades econômicas da Câmara contribuíam para a manutenção de tal estado ${ }^{21}$. Sabendo que o primeiro projeto urbanístico da cidade é da década de 194022, comprova-se que, até o início do século XX, pouco deve ter sido alterado no núcleo central em relação ao loteamento do início do século XIX.

Mesmo que tenham ocorrido algumas alterações na estrutura viária, pouco foi mudado no formato dos lotes na área central. Isso pode ser confirmado no levantamento das plantas dos quarteirões curitibanos entre as décadas de 1920-1950. Essa documentação quase não tem sido explorada, mas é de grande utilidade para os estudos do desenho da cidade. Através dessas representações, puderam ser reconstituídos, em grande medida, os trechos apagados pelas reformas urbanísticas nos quarteirões mais centrais.

Quanto a Antonina, a situação é mais complicada, pois dela não foram localizadas plantas relativas ao século XIX ou ao início do século XX. A única representação da cidade encontrada para esse período é a do pintor inglês William Lloyd, de $1872^{23}$, mas o ângulo escolhido não favorece a visualização do loteamento da cidade. Por essa insuficiência - e pela comprovação da permanência do loteamento e arruamento urbanos nas outras cidades acreditamos que, homologamente, Antonina deve ter conservado boa parte do seu loteamento central.

Dificuldades financeiras devem ter bloqueado maiores reformas. Na realidade, as grandes mudanças que ocorreram em Antonina foram resultado do loteamento parcial posterior do grande campo central da vila. Mas isso possivelmente não significou a alteração da trama viária nem do loteamento antes existente.

Na tentativa de retroagir as plantas atuais para a época em estudo, elas foram confrontadas com outras representações (principalmente gravuras das cidades) produzidas no século XIX, como as de Debret2 ${ }^{24}$, e plantas (do século $X X$ ) dessas três cidades, existentes nos arquivos de suas prefeituras, que nos permitiram constituir uma base sólida, ainda que pequena, de representações das vilas examinadas. Complementam esse quadro as descrições dos naturalistas Saint-Hilaire e Martim Andrada que, no início do século XIX, fizeram viagens pela região ${ }^{25}$. 
A etapa seguinte foi outro exercício bastante complexo: localizar, nessas p. 75$)$. plantas-base, igrejas e outras edificações civis que existiam no início do século XIX, pois, devido a reformas na estrutura física das cidades, algumas delas tinham sido demolidas. A tarefa foi uma etapa importante, porque, na documentação, alguns imóveis estavam referenciados a partir dessas edificações notáveis. Então, conhecendo o sítio das igrejas, por exemplo, as casas poderiam ser localizadas com maior precisão. No caso das igrejas, essa tarefa foi bastante simples, porque quase todas as igrejas existentes naquelas vilas no início do século XIX permaneciam em seus sítios até o momento da pesquisa. Já no caso dos pelourinhos, casas de câmara e cadeia, e fontes de água, a reconfiguração foi bastante penosa.

$\bigcirc$ pelourinho era o símbolo da presença do Estado português em todos os seus territórios no ultramar - não apenas uma baliza física, mas também um marco psicológico, representando o embate da civilização contra a barbárie. Daí o cuidado, no início da ocupação portuguesa na América, com sua construção e manutenção ${ }^{26}$. Porém, com a passagem do tempo, os homens que foram chegando não tiveram a mesma preocupação, pois, provavelmente, o símbolo foi perdendo seu significado e função. E, talvez por isso mesmo, hoje em dia não seja possível localizar onde esteve erigido o pelourinho de Antonina. Na prefeitura nem em nenhuma fonte do período colonial se encontra qualquer indicação ou relato acerca do local desse marco urbano e, infelizmente, assim, é impossível situá-lo.

Já em Curitiba, a localização do pelourinho é controversa. Em 1968, a prefeitura inaugurou um bloco de pedra - na atual praça José Borges de Macedo anexa à praça Tiradentes (endereço da antiga lgreja Matriz) considerando-o como local do antigo pelourinho. Apesar de vários pesquisadores reproduzirem esse mito, não há documento que sustente tal localização e, desse modo, na ausência de fontes cabais, preferimos não adotar como "o " correto nenhum dos sítios já aventados.

Quanto ao pelourinho de Paranaguá, ele deve ser o único que continua em seu local original. Está no lote da sede do Instituto Histórico e Geográfico da cidade, na rua 15 de novembro, 621 . Como não temos fontes que indiquem um antigo posicionamento (nem informações divergentes), optamos por adotar a situação atual. Enfim, na estrutura física das vilas, o pelourinho era um dos referenciais mais importantes, mas não era o único. Outro marco físico importante eram as casas de câmara e cadeia - geralmente o mesmo edifício abrigava as duas funções -, daí a necessidade de localizá-las.

Segundo o arquiteto Murillo Marx, no Brasil colonial o costume era alugar uma casa para as reuniões camarárias ${ }^{27}$, pois a maioria das vilas não dispunha de recursos para financiar a construção do prédio da Câmara, também chamada Concelho. Pelo menos até a década de 1720, essa era a situação das vilas analisadas. Condição que teria se modificado com a visita do ouvidor Rafael 
28. Cf. Auguste Saint-Hilaire (1995, p. 106).
Pires Pardinho a Paranaguá e Curitiba, quando deu ordens para que se construíssem edifícios próprios para as atividades camarárias.

No início do século XIX, as casas de câmara de Curitiba e Paranaguá já funcionavam em edifícios próprios, construídos no século XVIII. Essa não era, porém, a inteira realidade dos fatos. Segundo o livro de imposto predial de 1810, em Curitiba eram alugados ainda dois imóveis para a Câmara - um na rua Fechada, outro no pátio e largo da Matriz. Já o Concelho parnanguara funcionava na rua da Praia, em uma casa pertencente ao tenente-coronel Ricardo Carneiro dos Santos. É razoável pensarmos que isso ocorria por não estarem os edifícios próprios em condições de uso. Se até a Matriz tinha necessidade de reformas urgentes, por que as paredes estavam por cair (ou caindo), por que não a casa do Concelho?

Já para Antonina, não se sabe se houve ordens, no início do século XIX, para a construção de uma casa específica para tais atividades. Em 17201721, as ordens do ouvidor Pardinho não incluíam Antonina (elevada a vila só em 1797), que então pertencia à freguesia de Paranaguá. Sabe-se que, em 1808, o Concelho de Antonina funcionava em casa alugada, na rua Direita, pertencente aos órfãos de Leão Alves Rodrigues.

Finalmente, mas não menos importante, tratou-se de localizar os equipamentos urbanos que forneciam água para a população. Na maior parte das cidades luso-brasileiras, as fontes de água eram denominadas "cariocas". Quando esteve em Curitiba, Saint-Hilaire registrou que havia duas bicas de água, sem, contudo, localizá-las ${ }^{28}$. Estavam, provavelmente, próximas a dois logradouros cujos nomes remetiam à sua existência: as ruas da Carioca la de baixo e a de cima). A localização da fonte na Carioca de Baixo (fonte que já não existe atualmente) foi feita a partir de documentos do século XIX: representações, plantas e uma maquete de 1876. A outra "carioca" estava (e continua lá) no largo da Igreja do Terço (atual largo da Ordem).

Em Paranaguá, o naturalista não se deteve no modo como a população se abastecia de água. Pela ausência de fontes camarárias, não foi possível identificar a denominação utilizada para a "carioca" local. Nenhum dos topônimos arrolados na Décima remetia a esse acidente da topografia. Contudo, provavelmente desde os primeiros anos da vila, pelo menos uma fonte abastecia a população local e localizava-se no final da rua da Gamboa latual rua Conselheiro Sinimbu). Já em Antonina, um logradouro remetia à existência de tal equipamento urbano - a rua da Fonte -, localizada hipoteticamente na atual rua Marquês do Herval. Em um período posterior (1867), uma nova "carioca" foi inaugurada (a Fonte da Carioca, na atual praça Doutor Carlos Gomes da Costa) dando seu nome a outra parte da vila.

Topônimos

O exercício subsequente foi assinalar - nas plantas-base do atual arruamento das cidades examinadas - a localização dos antigos topônimos 
arrolados na Décima. Esse problema surgiu ao confrontarmos as denominações dessas duas épocas. Diferentemente de hoje, as ruas e travessas criadas no período colonial não tinham nomes oficiais. Além disso, era comum, pelo menos até a primeira metade do século XIX, mudarem-se os topônimos e não registrar tal mudança nas atas da Câmara, o que foi o caso em Curitiba, cujas mudanças nos topônimos, principalmente a partir da década de 1870, foram aí anotadas.

\section{Paranaguá}

Com o auxilio das listas nominativas de 1767 e de 1772, e da Memória histórica de Vieira dos Santos, de 185029, que registra nomes dos logradouros de Paranaguá, conseguimos relacionar tais topônimos com os onze arrolados na Décima, de 1808. As listas não trazem dados para a localização dos logradouros, mas indicam a existência de alguns deles já no terceiro quartel do século XVIII. Vieira dos Santos foi minucioso nas informações sobre as ruas de meados do XIX, apontando proprietários, toponímia das ruas naquele momento, e eventuais nomes de ruas, e de proprietários, em tempos anteriores ${ }^{30}$. A historiadora Cecília Westphalen (1974, entre p. 528-529) espacializou os topônimos de Vieira.

Essa planta nos auxiliou a pensar o arruamento de Paranaguá em 1850 e em décadas anteriores. Em alguns casos, logradouros com esses mesmos topônimos foram relacionados também na Décima. Outros, parece que não resistiram no tempo. A comparação entre os documentos possibilitou arrolar, ainda que com certo grau de dúvida, antigos topônimos dos atuais logradouros. $\bigcirc$ resultado está na Tabela 1.

\section{Tabela 1}

Nome de ruas e travessas de Paranaguá em diferentes épocas*

\begin{tabular}{|c|c|c|c|}
\hline 1767 ou 1772 & 1808 & 1850 & 1999 (hoje) \\
\hline rua do Terço & rua do Terço & $\begin{array}{l}\text { rua da Cadeia } \\
\text { e da Ordem }\end{array}$ & rua 15 de Novembro \\
\hline rua da Praia & rua da Praia & rua da Praia & rua General Carneiro \\
\hline$[?]$ & $\begin{array}{l}\text { rua do "Chargo" ** } \\
\text { (Charco) }\end{array}$ & [rua do Ouvidor] & rua Pêcego Junior \\
\hline $\begin{array}{l}\text { [rua da Matriz para } \\
\text { a do Terço] }\end{array}$ & rua do Porto da Matriz & [travessa do Rosário] & rua Professor Cleto \\
\hline $\begin{array}{l}\text { [rua da Matriz para } \\
\text { a Gamboa] }\end{array}$ & rua da Gamboa & rua da Gamboa & rua Conselheiro Sinimbu \\
\hline rua do Fogo & rua do Fogo & rua do Fogo & rua Vieira dos Santos \\
\hline rua do Campo & rua do Campo & rua da Misericórdia & rua Doutor Leocádio \\
\hline rua da Baixa & rua da Baixa & rua do Ouvidor & rua Faria Sobrinho \\
\hline
\end{tabular}

29. Ver Antonio Vieira dos Santos (2001).

30. Idem, v .2,. p. 13-21. 
31. Ver Paranaguá. (1767).

32. Cf. Jornal Dezenove de Dezembro, Curitiba, $6 \mathrm{fev}$ 1856, ano 2,n.45,p.4. Não há anotação de autoria na seção de Anúncios deste jornal de circulação semanal.

33. Cf. Waldomiro F. Freitas (1999, p. 449).

34. Cf.Antonio Alvarez (1928, p. 1).

35. Ver Paranaguá. (1772,f. 8 [p. 186 do arquivo digital]).

36. Cf. Leônidas Boutin (2003, p. 83).

37. Cf.Antonio Vieira dos Santos (2001, v. 2, p. 14)

38. Cf. Jornal Dezenove de Dezembro, Curitiba, 4 abr. 1856 , ano 2 , n. 3, p. 4. Ver seção de Anúncios.

\begin{tabular}{lllll}
\hline $\begin{array}{l}\text { rua Direita do Bom } \\
\text { Jesus para as Mercês }\end{array}$ & rua Direita & rua Direita & rua Marechal Deodoro \\
rua do Funil & travessa do Funil & [travessa das Flores] & $\begin{array}{l}\text { rua Desembargador } \\
\text { Hugo Simas }\end{array}$ \\
travessa da Matriz & travessa da Matriz & rua da Matriz & rua João Régis \\
\hline
\end{tabular}

Fontes: Listas Nominativas de Paranaguá, de 1767 e 1772; Décima urbana de Paranaguá (1808); Vieira dos Santos [1850], (200 1); e Planta Cadastral de Paranaguá (1999).

Notas: * $O$ nome (anterior ou posterior) suposto possível do logradouro arrolado na Décima de 1808 está entre colchetes. * * A palavra "chargo" inexiste em língua portuguesa; Houve, provavelmente, um erro de grafia do escrivão. Era charco:: terreno baixo e alagadiço onde a água se espalha, como é comum em regiões litorâneas.

A rua da Praia foi, provavelmente, um dos primeiros logradouros a constituir-se. Corresponde a uma parcela da atual rua General Carneiro. Essa relação foi estabelecida em consonância com a planta hipotética de Westphalen. Apesar da antiguidade, o registro mais remoto, encontrado na primeira Lista nominativa da vila ${ }^{31}$, é de 1767. Na Décima de 1808 foram arroladas doze casas $-75 \%$ eram residências que provavelmente agregavam comércio, e o percentual restante, edifícios exclusivamente comerciais.

Em 1850, a rua da Praia era densamente ocupada por armazéns e algumas residências, invertendo, portanto, a situação encontrada no início do mesmo século. Com base em referências aos antigos proprietários, confirmamos que se tratava do mesmo logradouro arrolado na Décima. Parece que, em 1856 , a denominação continuava igual, por registro encontrado no jornal Dezenove de Dezembro ${ }^{32}$. Ainda no século XIX, de acordo com o memorialista local Waldomiro Ferreira Freitas, a rua da Praia primeiro passou a ser denominada rua Rodrigo Silva e, mais tarde, em 1894, recebeu a denominação com que hoje a conhecemos $^{33}$. Não obstante essas alterações oficiais do final do século XIX, os moradores continuavam a utilizar, em 1928, o topônimo mais antigo ${ }^{34}$.

Já o atual topônimo da antiga rua do Terço é rua 15 de Novembro. Era o logradouro que, da via que ligava o porto à Matriz, partia para a lgreja da Ordem Terceira. Nessa rua se localizava o Colégio Jesuíta, um imponente edifício de três andares, que serviu posteriormente de alfândega e, hoje, abriga - Museu de Arqueologia e Etnologia da Universidade Federal do Paraná (MAE). Na Lista Nominativa de 1772, ela foi inventariada com o nome de "rua do Terço até a da Barranceira inclusa a rua do Funil"35. Em 1808, era o logradouro com o segundo maior número de edificações (55 casas) arroladas na Décima.

De acordo com outro memorialista, em 1850, a rua do Terço mudou de nome, tornando-se a rua da Cadeia e da Ordem ${ }^{36}$. Essa associação pode ser feita também a partir dos nomes dos antigos proprietários - arrolados por Vieira dos Santos $^{37}$, e presentes no livro de imposto predial -, sendo confirmada pela venda um imóvel, em 1856, na rua da Ordem em frente à alfândega ${ }^{38}$. Segundo Waldomiro de Freitas, um trecho da rua do Terço passou a ser denominado, ainda 
no século XIX, rua do Hospício, passando sucessivamente a ser conhecida como da Alfândega, do Paissandu, do Imperador e, desde 1890, rua 15 de Novembro ${ }^{39}$.

A rua da Baixa atravessava o meio da vila, correspondendo à atual rua Faria Sobrinho. Sua existência remonta, pelo menos, a 1720. Na época, foi citada pelo ouvidor Rafael Pires Pardinho, que, devido ao alagamento de parte do logradouro, acusava necessidade de aterrá-la (por ser inclinada, tendo sua parte mais baixa no centro da vila); provavelmente provém daí essa denominação ${ }^{40}$. Em 1772, foi registrada como tal na Lista Nominativa ${ }^{41}$. Em algum momento entre 1808 (quando tinha 24 casas) e 1850 - talvez em 1844 -, teve seu nome alterado para rua do Ouvidor ${ }^{42}$. Confirma-se ser essa a denominação usada 1855, pois ela consta em um anúncio de jornal${ }^{43}$. Segundo Waldomiro Freitas, tal designação perdurou até 1879, quando a Câmara nomeou-a rua Pêcego Junior 44 .

Em consonância com a planta da historiadora Westphalen, a rua Direita é a atual rua Marechal Deodoro. Com a denominação de "rua Direita do (capela) Bom Jesus para as mercês", sua existência remonta, pelo menos, a 1772, incluída em uma Lista Nominativa ${ }^{45}$. Cinco anos antes, em documento análogo, talvez ela seja a rua referenciada como "do Bom Jesus", porque era o caminho para chegar àquela igreja ${ }^{46}$. Dos logradouros arrolados na Décima, era a rua com maior número de edificações (6l casas). Em 1850, era bastante larga; e é bom não confundir "direita" com "direta" (reta), pois a rua tinha alguma curvatura. Em 1855, ainda mantinha, possivelmente, sua denominação mais antiga ${ }^{47}$. Essa situação teria perdurado até as últimas décadas do século XIX, quando passou a ser rua da Imperatriz (após 1880); e, desde 1890, com a República, passou a ter o nome como é conhecida hoje ${ }^{48}$.

A hoje conhecida como rua Doutor Leocádio é a antiga rua do Campo - denominação com que foi registrada na Lista Nominativa de 1767. Bastante reta e extensa, era, segundo Vieira dos Santos, um dos mais antigos logradouros da vila ${ }^{49}$. Em 1808, tinha 34 imóveis. Em algum momento entre a primeira Décima (1808) e 1850 - talvez em 1841 - teve seu nome alterado para rua da Misericórdia ${ }^{50}$. O novo nome da antiga ligação com a zona do campo provavelmente foi sugerido por ser o percurso que dava acesso à Santa Casa. A denominação até hoje vigente é, segundo Waldomiro Freitas, de $1887^{51}$.

Uma parcela da atual rua Conselheiro Sinimbu chamava-se rua da Gamboa. Provavelmente é a que está anotada como "rua da Matriz para a Gamboa" na Lista Nominativa de 1767. Era o caminho entre o pátio da Matriz e a Igreja de São Benedito. Também pode ter sido rua da Fonte, o principal acesso ao chafariz que ficava em frente da lgreja de São Benedito ${ }^{52}$. Em 1850, - logradouro era bastante reto e largo, e tinha 39 casas, o que lhe dava o terceiro lugar entre os com maior número de imóveis arrolados.

Paralela, estava a rua do Fogo (corresponde à atual rua Vieira dos Santos), que já aparece na primeira Lista Nominativa da vila, de 1767. Em 1850, ainda mantinha o mesmo nome e era o principal local do comércio. No
39. Cf. Waldomiro F. Freitas (1999, p. 449),

40. Cf. Antonio César de A Santos (2000, p. 118).

41. Cf. Paranaguá (1772,f. 11 [187]).

42. Cf. Waldomiro F. Freitas (1999, p. 459); eAntonio Vieira dos Santos (2001, v. 2, p. 15).Vieira dos Santos relatou a mudança de nomenclatura do topônimo, mas a indicação do ano foi de Freitas.

43. Cf. Jornal Dezenove de Dezembro, Curitiba, 13 jun. 1855, ano 2, n. 11, p.4.Ver na seção de anúncios.

44. Cf. Waldomiro F. Freitas (1999, p. 459)

45.Ver Paranaguá (1772, f. 1 [182]).

46. Idem, 1767.

47. Cf. Jornal Dezenove de Dezembro, Curitiba, 26 set. 1855 , ano 2 , n. 26 , p. 4 . Ver seção de Anúncios.

48. Cf. Waldomiro F. Freitas (1999, p. 453).

49. Cf.Antonio Vieira dos Santos (2001, v. 2, p. 19-20).

50. Idem, ibidem. E, também Waldomiro F. Freitas (1999, p. 453). O memorialista Vieira dos Santos relatou a mudança de nomenclatura do topônimo, mas a indicação do ano foi de Freitas.A mudança deve ter ocorrido pela criação de uma nova rua, de mesmo topônimo, em outro local. $\mathrm{O}$ nome dessa antiga rua do Campo não fazia mais jus à sua localização: estava no meio da vila; assim o nome foi dado a esse novo local, essa nova rua do Campo.

51. Cf. Waldomiro F. Freitas (1999, p. 453).

52. Idem, p. 454; e também Antonio Vieira dos Santos (2001, v. 2, p. 17). 
53. Cf. Waldomiro F. Freitas (1999, p. 448).

54. Cf. Paranaguá (1772, f. 8 [186]).

55. Cf. Jornal Dezenove de Dezembro, Curitiba, 2 jan. 1856 , ano 2 , n. 40 , p. 4 . Ver seção de Anúncios.

56. Cf. Waldomiro F. Freitas (1999, p. 445).

57. Cf.Antonio Vieira dos Santos (2001, v. 2, p. 20).

58. Idem, p. 18-19. século XIX, seu nome mudou para rua Senador Dantas e, em 1906, recebeu a atual denominação ${ }^{53}$.

Também a travessa do Funil teve sua existência registrada na Lista Nominativa de 1767, mas como rua. Na Lista de 1772, estava incluída no arrolamento das casas da "rua do Terço até a da barranceira inclusa a rua do Funil"54. Na Décima (1808), já figurava como travessa e tinha 15 casas. Em 1850, figura uma travessa das Flores, que talvez fosse ela. Cinco anos depois, aparece a rua das Flores, como transversal da rua do Ouvidor (que, em 1808, era a rua da Baixa) ${ }^{55}$. Na nossa hipótese (em consonância com a planta de 1815), ela era - quando da execução da Décima - a fronteira leste do setor urbano, estando localizada onde hoje se encontra a rua Desembargador Hugo Simas. Foi descartada a hipótese de ela ser a atual travessa Correia de Freitas - paralela e mais externa que a atual Desembargador Hugo Simas -, cujo traçado também aparece na planta de 1815. Esse descarte se deve a existirem, hoje, duas ruas intermediárias entre a Igreja Matriz e essa travessa (na planta de 1815 existem apenas dois; ou seja, uma só rua intermediária) - e, em 1815, ela não ter os dois lados habitados, mas apenas um (os lotes do outro lado estavam sendo constituídos). A travessa do Funil que está arrolada na Décima têm os dois lados habitados (direito e esquerdo), corroborando nossa hipótese a favor da Desembargador Hugo Simas. Para chegar a essa localização, o número de casas foi decisivo, pois no outro local não haveria espaço para tantas. Em 1879, antes de chegar ao nome atual, a travessa do Funil passou a denominar-se rua Silva Lemos ${ }^{56}$.

A localização da rua do "Chargo" foi mais complexa. Não foi mencionada por Vieira dos Santos, apesar de sua existência ter sido registrada em Lista Nominativa da vila, de 1801 (onde não havia qualquer argumento que auxiliasse a sua localização). Supomos que corresponda à atual rua Pêcego Junior, em consonância com a planta de 1815. Na Décima, era o logradouro com menor número de imóveis (9).

Havia ainda dois logradouros que tinham seus extremos na praia e no pátio da Igreja Matriz: a rua do Porto da Matriz e a travessa da Matriz. Esses dois logradouros podem ter sido referenciados por Vieira dos Santos, em 1850, com novas denominações: respectivamente travessa do Rosário e rua da Matriz ${ }^{57}$. Optamos por localizar a rua do Porto da Matriz (1 5 casas) na atual rua Professor Cleto; enquanto a travessa da Matriz ( 18 casas) foi atribuída à atual rua João Regis. $\bigcirc$ número de casas de cada lado da rua determinou esse posicionamento.

Como tínhamos por base a atual planta cadastral, e tendo em vista a suposição de ter havido poucas alterações no loteamento, não era possível uma inversão, devido à ausência de espaço para o número de casas arroladas. Uma dessas localizações foi indiretamente confirmada por Vieira dos Santos, por haver, em 1850, na rua da Matriz, uma casa de sobrado pertencente aos herdeiros do capitão José Rodrigues Branco ${ }^{58}$, e, em 1808, o capitão residir em uma casa de sobrado na travessa da Matriz. Imaginamos que se tratava do mesmo valorizado imóvel. Assim sendo, por exclusão, o outro logradouro (ao lado) seria a rua do Porto da Matriz. 
A localização no atual arruamento antoninense dos logradouros 60. Cf. Ermelino A. de Leão (1999, p. 110). arrolados na Décima de Antonina foi exercício menos complexo, porém mais frustrante. Falta quase tudo: documentos, plantas, ilustrações da época. Por isso, para atribuirmos a identificação hipotética dos logradouros, utilizamos basicamente o trabalho de Sandro Gomes ${ }^{59}$.

Nessa comparação, no que tange à descontinuidade dos topônimos, pode-se chegar à mesma conclusão que nas outras vilas analisadas: desde o início do século XIX até hoje, nenhum deles sobreviveu, que se dirá daqueles acaso mais antigos. Diante da ausência de fontes, a solução foi basear-se nos esparsos referenciais de que dispomos e aliá-los à nossa percepção da lógica de loteamento urbano luso-brasileiro quanto ao formato dos lotes sobre os quais estariam as casas urbanas arroladas em 1808.

Ermelino de Leão, ao associar a rua Direita com a atual rua 15 de Novembro, foi o único a relacionar um antigo topônimo, do início do século XIX, com outro do começo do século XX, época em que escreveu sua memórias ${ }^{60}$. $E$, segundo Berg Clauss, talvez, antes de ser rua 15 de Novembro, a rua tivesse recebido o nome de rua do $\left.\right|_{m p e r a d o r}{ }^{61}$. Como em Paranaguá le em outras cidades coloniais), a rua Direita significava a ligação entre dois pontos importantes; no caso de Antonina, entre a lgreja Matriz e o porto.

As demais correspondências de logradouros foram feitas através de hipóteses e seguindo nossa experiência no trato das cidades coloniais e na observação in loco. A travessa para o mar foi considerada a antiga rua Direita e hipoteticamente localizada como continuação da atual rua 15 de Novembro, entendendo-a, como já dito, como caminho que levava da lgreja Matriz para o porto da vila, situado no final desse prolongamento.

A rua da Matriz, que também dava acesso, na época, à única igreja da vila, estaria do outro lado da rua Direita lem sua continuação na direção oposta). $\bigcirc$ formato dos lotes da atual rua Vale Porto e início da 15 de Novembro foi determinante para tal localização. Não há atualmente, no entorno dessa igreja, lotes que tenham características semelhantes - lotes estreitos e alongados, onde a testada é menor do que o comprimento -, típicas do loteamento colonial português. A rua da Fonte foi localizada em uma ladeira que levava a população para a bica de água, onde ainda existia, no início do século XX, uma fonte. Não se sabe quando passou a denominar-se rua Marquês do Herval.

conjunto de logradouros ligados ao campo (rua do Campo e travessa para o Campol foi localizado seguindo o mesmo raciocínio utilizado para a rua da Matriz. No caminho que (provavelmente) levava a população para as fazendas e sítios da região, existe grande número de lotes com as características já relacionadas. Por isso escolhemos a rua Conselheiro Alves de Araújo como local hipotético da antiga rua do Campo, e o seu prolongamento para a travessa homônima. 
Não conseguimos localizar o logradouro Ponta da Pedra, pela ausência de elementos documentais que pudessem indicar sua posição. Ademais, a presença de apenas uma morada inabitada - uma casa em ruínas e sem chefe - tornou desnecessária, para nossos fins, sua localização. Na Tabela 2 está o resultado hipotético da associação entre os topônimos relacionados na Décima antoninense e os atuais.

Tabela 2

Nome de ruas de Antonina, em duas épocas

\begin{tabular}{ll}
\hline \multicolumn{1}{c}{1808} & \multicolumn{1}{c}{2010} \\
\hline $\begin{array}{l}\text { rua da Matriz } \\
\text { rua Direita }\end{array}$ & rua Vale Porto e início da 15 de Novembro \\
travessa para o mar & ru 15 de Novembro \\
rua da Fonte & rua 15 de Novembro (final) \\
rua do Campo & rua Marques do Herval \\
travessa para o campo & rua Conselheiro Alves de Araújo \\
Ponta da Pedra & rua Conselheiro Alves de Araújo (final) \\
\hline
\end{tabular}

Fontes: Décima urbana de Antonina (1808); Planta Cadastral de Antonina (2010)

Infelizmente, pela falta de documentos, não foi possível - como fizemos para Curitiba e Paranaguá - acompanhar a mudança dos topônimos no decorrer dos tempos, desde a fundação da vila (1797) até hoje. Essa é uma frustração que dificilmente será minimizada, pois os homens e as traças não nos deixaram muitas opções.

\section{Curitiba}

De acordo com os dados tabulados da Décima de Curitiba, seu núcleo citadino era composto de 244 casas em doze logradouros. No maior deles - 0 pátio e largo da Matriz - estavam registrados 68 imóveis. Na rua do Fogo, foram arroladas 38 casas; e na rua do Lisboa, 29. Esses eram os logradouros mais extensos em quantidade de quarteirões e aqueles em que havia o maior número de imóveis. Já os menores, em nossa hipótese, não ultrapassavam um quarteirão, como a rua da Carioca de Baixo, onde havia 4 casas.

Na produção da planta hipotética de Curitiba, relacionamos com os atuais todos os topônimos arrolados na Décima de 1810 . Exceto a rua do Rosário, os demais logradouros tiveram seus nomes mudados. Para identificarmos a correspondência dos antigos topônimos, as fontes utilizadas foram plantas - de 1857 e de 1900 - e croquis dos quarteirões, produzidos, principalmente, entre as décadas de 1920-1950. Nessa tarefa fomos auxiliados pela planta de 18301850, pela maquete de 1876, e, iá no século XX, pelos levantamentos de 
estudiosos da cidade. A Tabela 3 resume a mudança de nomenclatura dos topônimos.

\section{Tabela 3}

Nome de praças, ruas e travessas de Curitiba em diversas épocas

\begin{tabular}{|c|c|c|c|c|}
\hline 1810 & 1857 & 1876 & 1900 & 2010 \\
\hline rua Fechada & rua Fechada & rua Fechada & rua José Bonifácio & rua José Bonifácio \\
\hline $\begin{array}{l}\text { rua Nossa } \\
\text { Senhora do Terço }\end{array}$ & [não relacionada] & [não relacionada] & $\begin{array}{l}\text { rua São Francisco } \\
\text { (seção) }\end{array}$ & rua São Francisco (seção) \\
\hline rua do Fogo & rua do Fogo & rua do Fogo & $\begin{array}{l}\text { rua São Francisco } \\
\text { (seção) }\end{array}$ & rua São Francisco (seção) \\
\hline $\begin{array}{l}\text { rua Nova da } \\
\text { Entrada }\end{array}$ & rua da Entrada & rua da Entrada & rua Aquidaban & rua Emiliano Perneta \\
\hline rua do Lisboa & rua da Carioca & rua da Carioca & rua do Riachuelo & rua Riachuelo \\
\hline $\begin{array}{l}\text { rua da Carioca } \\
\text { de Cima }\end{array}$ & [não relacionada] & [não relacionada] & travessa da Ordem & rua Mateus Leme \\
\hline $\begin{array}{l}\text { rua São Francisco } \\
\text { de Paula }\end{array}$ & [não relacionada] & [não relacionada] & [não relacionada] & avenida Jaime Reis \\
\hline rua do Rosário & rua do Rosário & rua do Rosário & rua Rosário & rua do Rosário \\
\hline $\begin{array}{l}\text { pátio e largo da } \\
\text { Matriz }\end{array}$ & [não relacionada] & $\begin{array}{l}\text { largo da Matriz; } \\
\text { praça do Mercado }\end{array}$ & $\begin{array}{l}\text { praça Tiradentes; } \\
\text { praça Municipal }\end{array}$ & $\begin{array}{l}\text { praça Tiradentes; praça } \\
\text { Generoso Marques; praça } \\
\text { José Borges de Macedo }\end{array}$ \\
\hline $\begin{array}{l}\text { rua Nova das } \\
\text { Flores }\end{array}$ & rua das Flores & rua das Flores & $\begin{array}{l}\text { rua } 15 \text { de } \\
\text { Novembro }\end{array}$ & rua 15 de Novembro \\
\hline $\begin{array}{l}\text { rua da Carioca } \\
\text { de Baixo }\end{array}$ & rua do Comércio & rua do Comércio & $\begin{array}{l}\text { rua Marechal } \\
\text { Deodoro }\end{array}$ & rua Marechal Deodoro \\
\hline $\begin{array}{l}\text { rua do Jogo da } \\
\text { Bola }\end{array}$ & rua da Assembleia & rua Nova & rua da Assembleia & alameda Doutor Muricy \\
\hline
\end{tabular}

Fontes: Décima urbana de Curitiba (1810); Planta de Curitiba (1857); Maquete de Curitiba (1876); Planta de Curitiba (1900); e Planta cadastral de Curitiba (2007).

Como se pode perceber, algumas mantiveram seus topônimos até 1876, como as ruas Fechada e do Fogo. Para outras, variaram as alterações, como a rua do Jogo da Bola, que passou a ser a rua Nova, depois, da Assembleia e, finalmente, alameda Doutor Muricy. Não descartamos a possibilidade de que muitos desses topônimos (e outros) tenham coexistido.

A rua Nova da Entrada corresponde a um segmento da atual Emiliano Perneta. Era o início do caminho que ligava Curitiba às outras vilas do planalto curitibano (Castro e Lapa) e ao sertão de Guarapuava. Na Décima de 1810, 
62. Cf. Romário Martins (1922, p. 179).

63. Cf. Edilberto Trevisan (2000, p. 55).

64. Três proprietários vizinhos registrados nesse beco, em 1802, foram localizados, também como vizinhos, na Décima de 1810 na rua do Jogo da Bola. Cf. Tabelionato (n. 27, f. 48r.-v).

65. Tabelionato (n. 33, 1818 f. 87v.-88v).

66. Cf. Edilberto Trevisan (2000, p. 71).

67. Cf. Jornal Dezenove de Dezembro, Curitiba, 1. ago. 1855 , ano 2 , n. 18 , p. 4 . Ver seção de Anúncios.

68. Curitiba (v. 27, 1927, p. 71).

69. Cf. Igor Chmyz (2010, p. 11).

70. Curitiba (v. 33, 1927, p. 50).

71. Tabelinato. (n. 32, 1811, f. 14-15). era um logradouro com 12 casas, provavelmente apartadas do núcleo citadino, como sugerem representações posteriores.

Com a abertura de uma nova entrada (rua Barão do Cerro Azul) para a ligação com a estrada da Graciosa (que levava ao litoral), o logradouro que servia de caminho para o interior deixa de receber o epíteto "nova" e passa a ser apenas rua da Entrada: é assim que aparece na planta de 1857. Desde 1871, segundo o memorialista Romário. Martins, era denominada rua Aquidaban ${ }^{62}$. Entretanto, na maquete de 1876 permanece como "da Entrada". Na planta de 1900 está anotada a denominação Aquidaban. Em 1935, o cronista Edilberto Trevisan registra que o logradouro teve seu topônimo modificado para o atualb3.

A alameda Doutor Muricy foi considerada como correspondente à rua do Jogo da Bola. Para isso, levou-se em conta a planta de 1830-1850. Parece que, oito anos antes da Décima, tinha outro nome e passou a denominar-se beco de São Francisco de Paula (não confundir com a rua homônima arrolada na Décima) ${ }^{64}$, por ser o caminho para a capela de mesmo nome. $\bigcirc$ termo de compra de uma casa no pátio da Matriz aponta para a localização deste logradouro: "uma morada no Pátio da Matriz fundo fazendo frente para a rua Jogo da Bola"65. Conhecendo-se a localização dos outros logradouros arrolados em torno do referido pátio, restou uma única posição para a Jogo da Bola.

Em 1810, essa mesma rua tinha 16 casas. Segundo Trevisan, posteriormente - em período não indicado - o nome desse logradouro mudou para rua da Ladeira e, depois, para rua dos Quartéis ${ }^{66}$. Nas plantas de 1857 e 1900, era a rua da Assembleia. Em um anúncio de jornal de 1855, a denominação corrente era "da Assembleia"67. Na maquete de 1876 tinha outra denominação: rua Nova. Em ano que desconhecemos, tornou-se a alameda Doutor Muricy.

A rua do Rosário é tão antiga quanto a igreja homônima, que existe, pelo menos, desde 1737. É o único logradouro que, aparentemente, preservou seu nome praticamente intacto ao longo dos últimos séculos. Nas atas da Câmara de 1771, era a rua Nova de Nossa Senhora do Rosário68. Na Décima de 1810, foi arrolada já sem o qualificativo "nova", comportando 18 casas. Na planta de 1857, na maquete de 1876 e noutra planta (a de 1900), perdurava tal denominação e já se podia observar a mesma extensão que tem hoje (dois quarteirões).

Paralela a ela, a rua Fechada - então talvez com outras denominações - pode ter sido a primeira rua onde, provavelmente, já no final do século XVIII, os moradores edificaram suas casas ${ }^{69}$. No século seguinte, suas designações certamente variaram. Nas atas da Câmara, lemos: "rua que vai da Matriz da Igreja" (1740), "rua detrás da lgreja" e "rua Direita fronteira a Matriz" lambas em 17611. A partir de 1786, a denominação rua Fechada passou a ser registrada em atas da Câmara ${ }^{70}$. Essa antiga localização pode ser comprovada indiretamente pela escritura de venda, em 1811, de uma casa na rua Fechada que "fazia frente [sendo] os fundos para a rua do Rosário"71. Como conhecemos o lugar da rua 
do Rosário, situamos o outro logradouro. Eram ruas paralelas contíguas. Em um anúncio de emprego, de 1856, percebe-se a continuidade da denominação "Fechada"72. Esse nome aparece consagrado na planta de 1857 e na maquete de 1876. Segundo o historiador Ruy Wachowicz, no final do XIX, depois da demolição da Igreja Matriz (e, portanto, do motivo do nome), recebeu a denominação de rua do Chafariz ${ }^{73}$. Na planta de 1900 já aparece como rua José Bonifácio, seu atual topônimo. Outros pesquisadores apontam a mesma localização ${ }^{74}$.

Uma das ruas mais antigas da vila de Curitiba era a rua do Fogo, cujo topônimo parece ter sido pouco alterado no decorrer dos séculos. Não se sabe exatamente o porquê desse nome, entretanto era denominação muito comum em ruas luso-brasileiras (talvez porque, em uso antigo, a palavra fogo significava "casa de habitação, teto, abrigo", e nelas houvesse algum local onde os itinerantes pudessem pernoitar, e aquecer sua comida). Na Décima de 1810, comportava 38 casas, dentre as quais um terço estava em ruínas, o que remete à falta de cuidado dos seus proprietários. Pela sua posição na planta de 1857 - então já com dois quarteirões, que ainda se conservam - corresponde à atual rua São Francisco. Dois anos antes, era o local de uma nova "casa de pasto" lum restaurante) e de um hotel que servia refeições ${ }^{75}$. Esse mesmo topônimo antigo continua na maquete de 1876. Posteriormente, foi denominada rua do Hospício, nome alusivo à hospedaria ali construída ${ }^{76}$.

Além de registrada na Décima, a rua do Lisboa também consta em uma ata da Câmara, de 1796. Contudo, o escrivão não anotou, aí, qualquer outro acidente da topografia urbana que nos auxiliasse a localizá-la. Por sorte, outra ata, de 1835, indicou a localização deste logradouro - rua do Lisboa "em beco em frente à rua do Fogo"77. Conhecendo a localização da segunda rua, pudemos inferir a posição da primeira.

No livro de imposto predial de 1810, a rua do Lisboa era o terceiro logradouro com maior número de casas (29). Não conseguimos apurar por que tinha esse nome; talvez fosse o sobrenome de algum homem-bom que ali residiu. Em 1857, aparece como rua da Carioca, por ser caminho para uma fonte que, provavelmente, ainda não existia no início do século XIX. Segundo Trevisan - que, entretanto, não indica as datas -, teve o nome de rua dos Veados e rua da Carioca do $\mathrm{Campo}^{78}$. Segundo o mesmo autor, recebeu a atual denominação - rua Riachuelo - em $1871^{79}$. Contudo continua prevalecendo, na maquete de 1876, a denominação "da Carioca". A historiadora Roseli Boschilia elaborou uma hipótese da localização, em fins do século XIX e início do XX, das casas de comércio deste logradouro ${ }^{80}$. Utilizamo-nos desta espacialização para pensarmos o loteamento urbano na passagem do século.

Outro documento reconfirma o local da rua do Lisboa. Em uma ata da Câmara de Curitiba, no já distante ano de 1841, consta: "leu-se um ofício do alferes Jose Borges de Macedo pedindo carta de data de oitenta palmos de chãos para casa na rua das Flores diante das casas que está fazendo Jose Joaquim da Costa onde deve ser canto, e face com a rua do Lisboa"81 (Figura 1). Com a
72. Cf. Jornal Dezenove de Dezembro, Curitiba, 27 fev. 1856 , ano 2 , n. 48 , p. 4 . Ver seção de anúncios.

73. Cf. Ruy Christovam Wachowicz (1998, p.156)

74. Cf. Romário Martins (1922, p. 172); e Ruy Christovam Wachowicz, (1993, p. 27).

75. Cf. Jornal Dezenove de Dezembro, Curitiba, 11 jul. 1855 , ano 2 , n. 15 , p. 6. Cf. Jornal Dezenove de Dezembro, Curitiba, 17 out. 1855 , ano 2 , n. 29, p. 4 . Ver seções de Anúncios.

76. Cf. Edilberto Trevisan (1996, p. 107).

77. Cf. Curitiba (v. 47, 1930, p.90-91).

78. Cf. Edilberto Trevisan (1996, p. 139).

79. Idem, p.137.

80. Cf. Roseli Boschilia (1996, n.110, p. 79)

81. Cf. Curitiba (v. 52, 1931, p.99). 
82. Cf. Jornal Dezenove de Dezembro, Curitiba, 27 jun. 1855, ano 2, n. 13, p. 4 . Ver seção de anúncios.

83. Cf. Edilberto Trevisan (1996, p. 109).

84. Tabelionato (n. 30, 1808, f. $74 \mathrm{v} .-75 \mathrm{r})$.

85. Cf. Boschilia (1996, n. 113, p. 101-105). relativa certeza da posição da rua das Flores, e observando a planta de 1857 , o único local possível era a atual "Riachuelo". Para permitir essa associação, em algum momento (entre a elaboração da Décima e aquele ano), esses logradouros devem ter-se "encontrado".

Rua 15 de Novembro é o atual topônimo da antiga rua Nova das Flores. Em 1810, no livro de imposto predial, nela foram registradas 17 casas. Em 1855, já aparece sem o epíteto "nova"82. Tal situação está confirmada na planta de 1857 e, depois, na maquete de 1876. Posteriormente foi denominada rua da Imperatriz ${ }^{83}$, e o nome atual já está registrado na planta de 1900. Sua localização está indicada numa nota, de 1808, de um tabelião, ao registrar a negociação de um imóvel que tinha como um dos lados, "uma travessa que ia para a carioca" 84 . Portanto, permite pensar que poderia ser uma esquina entre duas ruas. Atualmente, coexistem para o mesmo logradouro os topônimos "das Flores" e "15 de Novembro".

Para o período entre o final do século XIX e início do XX, a historiadora Boschilia reconstruiu o logradouro em uma planta, o que foi útil para confirmarmos - apesar de isso não estar explicitado pela autora - a permanência do loteamento ${ }^{85}$.
Figura 1 - Provável localização do lote requerido pelo alferes José Borges de Macedo em Curitiba, 1841. [Diagramação: cuidar da fixação da seta indicadora do Norte, que está "solta", aqui e nas outras figuras]

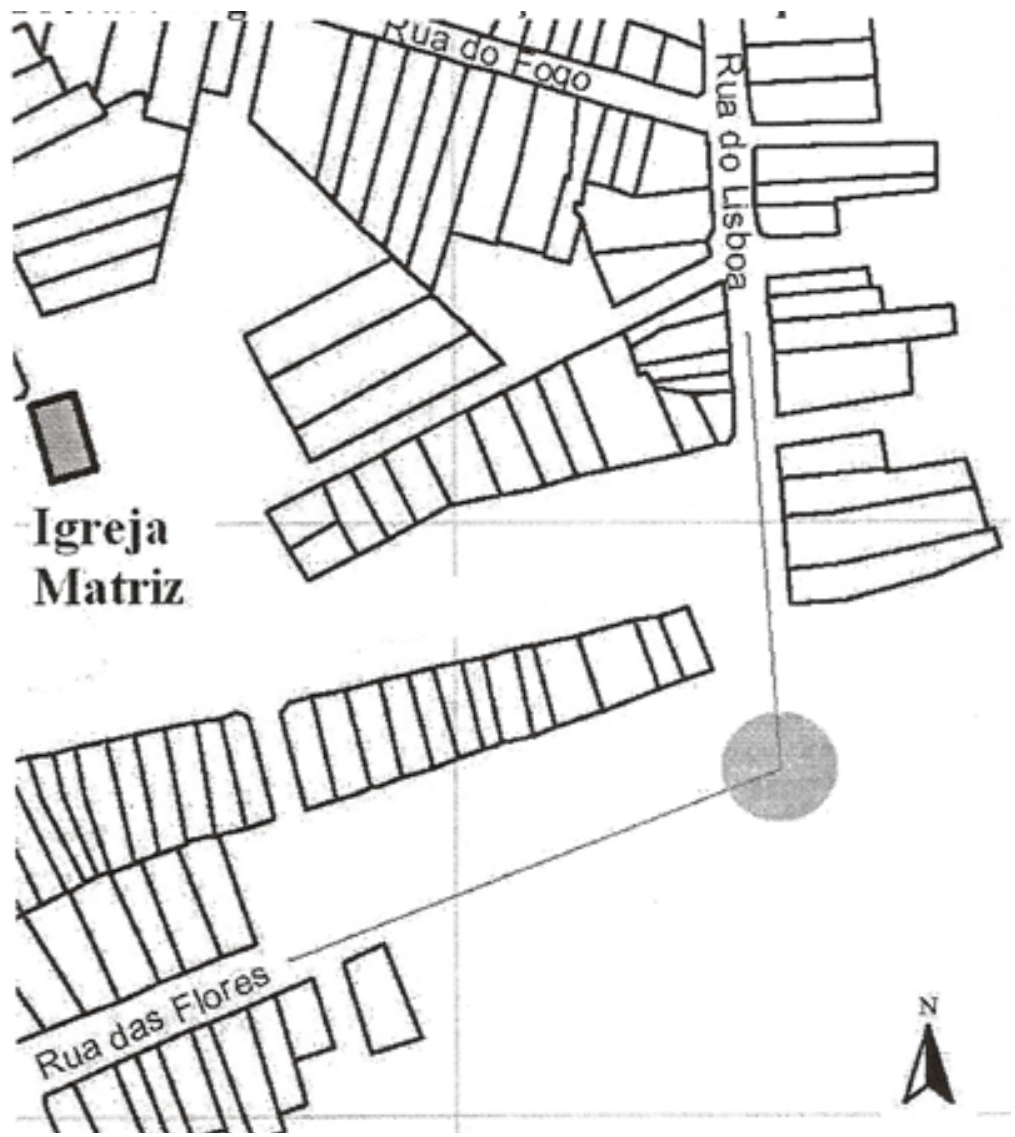

Anais do Museu Paulista.v. 20.n.1. jan.-jun. 2012. 
A rua da Carioca de Baixo corresponde a uma parcela da atual Marechal Deodoro. Recebeu essa designação, provavelmente, por estar próxima a uma das fontes de água da cidade. Em 1810, era o logradouro com menor número de casas (4), e aparece com esse mesmo nome na planta de 1830-1850. Pode ter sido mencionada, desde 1855, como rua do Comércio, e assim continuou pelo menos até 1876, quando foi registrada com esse nome na maquete ${ }^{86}$. Pode ter recebido o topônimo de rua do Imperador no final do século XIX87. Mas na planta de 1900 já aparece com a atual denominação.

Para os demais logradouros que aparecem na Décima las ruas da Carioca de Cima, de Nossa Senhora do Terço, de São Francisco de Paula), não foram localizados registros em representações ou em documentos camarários.

Decidimos considerar que a rua da Carioca de Cima corresponde à atual rua Mateus Leme, pois em seu início está a mais antiga fonte de água ("carioca") da cidade. Os historiadores Benatti e Sutil sugeriram, sem comprovação, localização diferente, por remeterem a outra "carioca", a do campo 88 , que provavelmente não existia em 1810 . Por terem tal nome, as ruas das "cariocas" deviam estar próximas a essas fontes de água. Observando a planta de 1857 e a maquete de 1876, entendemos que seria mais coerente as áreas centrais serem ocupadas antes das regiões mais afastadas na periferia do setor urbano. Por isso, a identificação desta rua com a atual Mateus Leme. Na planta de 1900, era a travessa da Ordem, possivelmente por ser ligação com a igreja homônima.

Atas da Câmara, de 1746, confirmam a existência da lgreja de Nossa Senhora do Terço ${ }^{89}$, mas não a da rua homônima. Diante do número de lotes nela arrolados na Décima - e seguindo o raciocínio utilizado ao associar a rua do Rosário com a igreja de mesmo nome -, arbitrou-se que a rua do Terço deveria ser o caminho para essa igreja. Por isso, corresponde, possivelmente, à atual rua Claudino dos Santos, como prolongamento da rua do Fogo. Em 1857, a região já era ocupada, como pode observar-se na planta. Seguindo pensamento semelhante, que liga igreja e rua homônimas, a localização da antiga rua de São Francisco de Paula corresponde, por hipótese, a uma parcela da atual avenida Jaime Reis. Apesar de seu nome não estar registrado na planta de 1857, foi atribuída tal localização ao logradouro tendo em vista as áreas ocupadas dessa planta.

Faltava ainda a situar o "Pátio e largo da Matriz". Mas esse não era o maior problema, pois, como o próprio nome indica, era provavelmente a região no entorno da lgreja Matriz. Mas o fato de na Décima haver dois nomes - pátio e largo -, levou-nos a conceber a existência de dois setores. Caso fosse uma só área, o escrivão (econômico como o foi nas palavras) não teria se dado ao trabalho de arrolar dois nomes para o mesmo lugar, ou teria incluído a palavra ou. Essa hipótese se confirmou no exame de escrituras de compra e venda entre 1780-1820. Nesse período, localizamos 14 casas sendo negociadas no pátio da Matriz, e duas outras no largo homônimo. Na nossa hipótese, os lotes desses imóveis (aqueles cuja localização pôde ser identificada, seja ou no pátio ou no largo) estavam nas mesmas áreas indicadas nas escrituras, isto é, as duas áreas
86. Cf. Jornal Dezenove de Dezembro, Curitiba, 23 maio 1855, ano 2 , n. 8, p.4. Ver seção de anúncios.

87. Cf. Edilberto Trevisan (2000, p. 102-103).

88. Cf. Antônio P.Benatti e Marcelo S. Sutil (1996, p. 7).

89. Curitiba (v. 18, 1925, p. 60). 
90. Cf. Maria da Conceição F. Ferreira (1989, p. 98-99); e Murillo Marx (2003, p. 31) não se confundiam. Tudo indica que os moradores as percebiam como áreas diferentes, e isso se refletia em seus nomes.

Direção e lados das ruas

O passo seguinte foi tentar determinar, nos logradouros, a direção (do início para o fim) e os lados (esquerdo e direito) em que as casas foram contabilizadas nos livros de registro da Décima urbana. Para a maioria das ruas e travessas das três vilas analisadas (70\%), houve pouquíssimo cuidado dos escrivães no registro dessas informações. Por isso, foi imprescindível definir qual a lógica que eles utilizaram ao arrolar as casas urbanas.

Para tentar resolver tal problema, foi utilizado o sentido centro-periferia, isto é, considerou-se que as casas haviam sido inventariadas a partir das que estavam mais próximas à lgreja Matriz (ou a outras igrejas, no caso de Curitiba). Fizemos isso porque as praças e largos das igrejas matrizes costumavam ser tomados como centros simbólicos dos núcleos urbanos ${ }^{90}$.

Outra fonte - as Listas Nominativas de Habitantes de Paranaguá do início do século XIX - indica que as casas eram arroladas desta forma: do centro para fora. Nelas, os habitantes foram registrados de modo semelhante, com a diferença de que os escrivães não nos fornecem o lado em que estão situadas
Figura 2 - Localização hipotética do pátio e do largo da Matriz de Curitiba (1810)

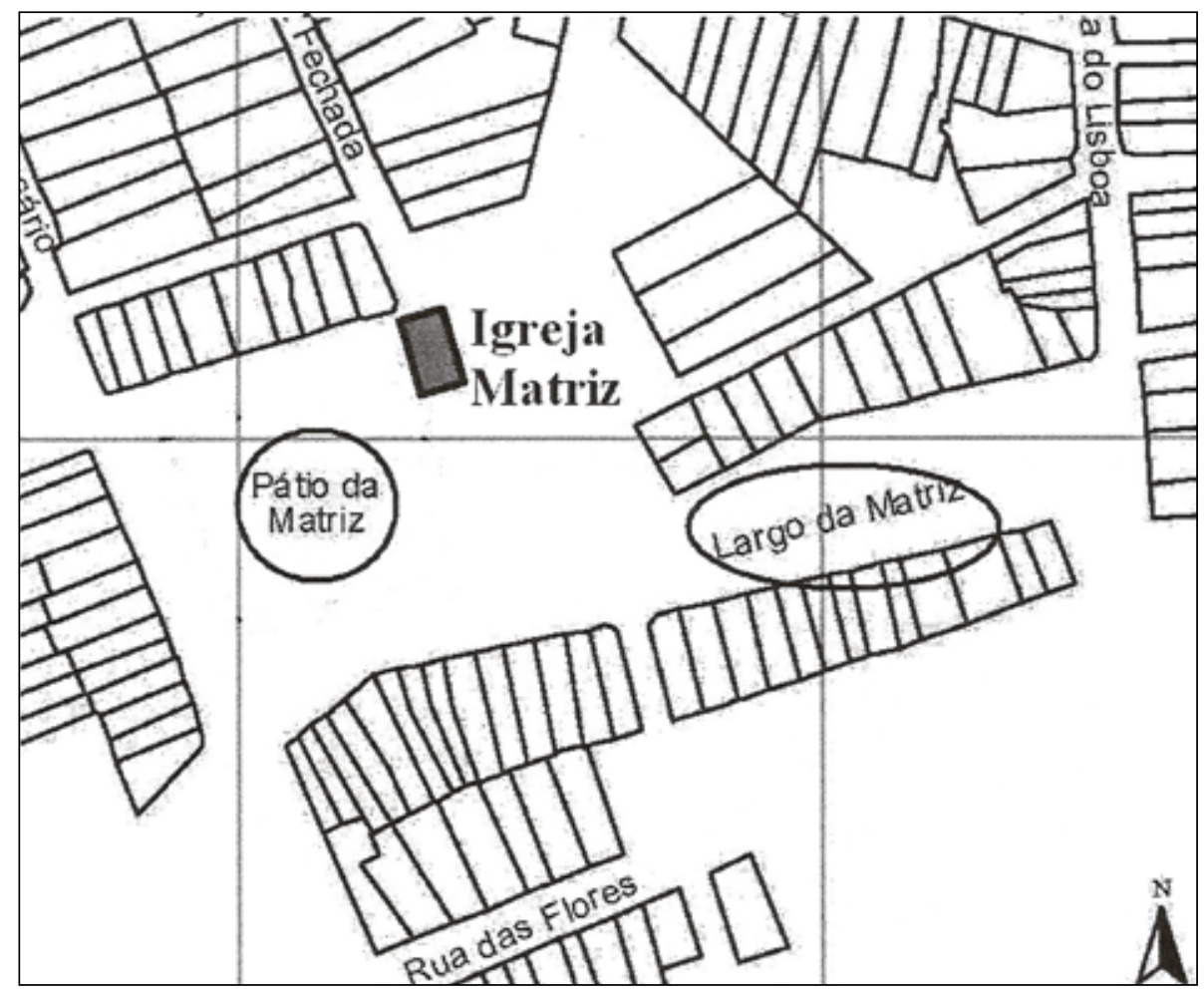


suas moradas. Em suas Memórias, Vieira dos Santos quase sempre utilizou o sentido centro-periferia no arrolamento dos logradouros ${ }^{91}$; e também reitera a posição central da lgreja Matriz no ordenamento da vila.

Em relação à Paranaguá, tal raciocínio serviu para definir o sentido das ruas da Praia, do Chargo, da Gamboa, do Fogo, do Campo, da Baixa, e Direita. Nas demais, a direção da contagem estava registrada, uma delas, a rua do Terço, indo para o (local da igreja de) São Francisco. Em outros três logradouros, essa lógica centro-exterior não foi seguida no arrolamento. Por indicação do próprio escrivão, na travessa da Matriz o arrolamento principiava na praia e, na rua do Porto da Matriz, ele foi feito vindo do mar; no caso da travessa do Funil - o único logradouro que não tinha um de seus extremos no Pátio da Matriz - nossa escolha foi considerar o início da rua em local próximo ao fim da rua do Campo, caminhando em direção à rua do Terço. Tal decisão foi tomada tendo em vista a referida planta de 1815 e o número de casas de cada lado da rua arroladas na Décima. Isto devido ao número de lotes de cada lado do logradouro, comparando-se com o espaço ocupado na planta de 1815, em que não seria possível dar o sentido inverso ao arrolamento das casas da rua.

Na sequência, definimos os lados (direito e esquerdo) das ruas e travessas parnanguaras. Com isso identificamos (hipoteticamente) que, na maioria dos logradouros (82\%), o primeiro lado arrolado foi o esquerdo; como ocorreu também na Décima de São Paulo92. Mas havia ruas em que a indicação de lado não foi feita ou têm lado único, como foi descrito pelo escrivão no caso da rua da Praia, de Paranaguá, por motivos óbvios: o outro lado é o mar. Já a rua do Fogo, na mesma vila, não teve anotada a indicação de lado, por isso utilizamos a mesma ordem centro-exterior, com a diferença de terem ficado do lado esquerdo três casas inabitáveis; e, do lado direito, as demais nove casas /de modo que, na Décima, a casa mais próxima fosse contada em sequência, mesmo que estivesse do outro lado da rua). Essa é a sequência mais lógica que foi possível imaginar observando a planta de 1815. Caso o arrolamento tivesse sido feito do mesmo modo que nas outras ruas, o escrivão teria novamente escrito lado esquerdo e lado direito, como era habitual.

Na Décima antoninense, o escrivão (o mesmo de Paranaguá) não foi tão minucioso na indicação do lado da rua em que se iniciou o arrolamento das casas: apenas para a rua Direita foram registrados os dois lados lesquerdo e direito). Os demais logradouros tiveram registrado o lado único, apenas um deles, ou sem lado. Para a rua do Campo, foi assinalado lado esquerdo único. Para a travessa para o Mar e rua da Matriz foi anotado somente o lado esquerdo. Para as demais (rua da Fonte e travessa para o Campo) não foram anotados os lados, - que nos forçou a colocar todas as casas arroladas nesses logradouros em um mesmo lado da rua ou travessa.

Assim se notou que, no caso das travessas para o Mar e para o Campo, havia uma direção consignada. $\bigcirc$ sentido desses dois logradouros corrobora a ideia de que a tendência era arrolar os imóveis partindo da lgreja Matriz para as bordas. Para as demais, não houve tal preocupação. Por isso, a
91. Cf.Antonio Vieira dos Santos (2001, v. 2, p. 13-21).

92. Cf. Raquel Glezer (2007, p. 105). 
mesma medida adotada para Paranaguá foi utilizada em Antonina: em alguns logradouros, o arrolamento das casas deve ter sido feito no sentido centro-periferia. No caso dessa última vila, provavelmente era ainda maior a importância da lgreja Matriz, por ser a única igreja urbana e, por isso, o principal motivo de reunião no núcleo citadino (além da Câmara).

Deste modo, pode-se perceber que, em Antonina, a rua da Matriz não teve, provavelmente, registrada as casas no sentido utilizado até agora (e que foi horizonte para todo o trabalho) - o escrivão deve ter catalogado as moradas em sentido periferia-centro, isto é, em direção à lgreja Matriz. Essa situação foi imaginada supondo que o lado esquerdo a que o escrivão se refere indica esse sentido, já que atualmente só existem lotes em um lado da rua.

Já o escrivão da Décima de Curitiba não teve o cuidado de anotar a direção, tampouco os lados em que estavam as casas arroladas. Por isso, o trabalho foi duplo: definir hipóteses para ambos os casos. Quanto ao sentido, adotou-se como referência, para a listagem das casas, a mesma noção de centralidade conferida à Igreja Matriz. Essa lógica foi seguida nas ruas que tinham início no pátio e largo da lgreja Matriz: a Fechada, a do Rosário e a do Lisboa. Para os logradouros em que não havia essa conexão, mas que tinham um de seus extremos ligado às outras igrejas (do Rosário e do Terço), foi atribuída igual lógica (centro-exterior), com a diferença de ter sido o arrolamento das casas feito a partir delas: ruas São Francisco de Paula, Nossa Senhora do Terço, Carioca de Cima, e do Fogo.

Para os demais logradouros onde não havia igrejas próximas, optamos por uma direção provável de registro, tomando como referência o número de casas arroladas na Décima. Na rua Nova da Entrada, o arrolamento deve ter tido início na ponte sobre o rio Ivo, em direção ao planalto, pois o referencial para esse logradouro afastado devia ser o conjunto citadino (urbano propriamente dito). Já a direção da rua Nova das Flores e a da Carioca de Baixo foi arbitrada levando em conta o caminho que levava ao litoral. Uma inversão de sentido no último logradouro não distorceria nossas conclusões, porque o número de casas (quatro) era pequeno. Por fim, o sentido de anotação dos edifícios da rua do Jogo da Bola foi suposto imaginando que o logradouro era o início do caminho para São Paulo.

Faltava definir o sentido em que foram registradas as casas no pátio e largo da Matriz, também não indicado pelo escrivão da Décima. Perguntamo-nos qual foi a ordem - se existente - do arrolamento das casas. Por compreendermos a lgreja Matriz como referencial simbólico, a suposição inicial foi que o escrivão teria começado a partir desse edifício e seguido o arrolamento pelos vizinhos de lote. Mas qual teria sido o passo seguinte? Qual a direção em que se arrolaram as moradas: em sentido horário ou no anti-horário?

O termo de compra de uma casa no pátio da Matriz nos sugeriu o sentido anti-horário. Em 1808, os proprietários venderam ao alferes José da Costa Pinto uma casa no pátio da Matriz, em que, no limite de um lado, estava o próprio comprador e, no do outro, estava $\circ$ "canto para a estrada que vai para os 
campos gerais"93. Pelo menos até a escrituração do imposto predial (1810), o alferes José manteve a propriedade desses dois imóveis, um ao lado do outro (casas numeradas 11 e 12 na Figura 3) ${ }^{94}$. Se nossas considerações iniciais estiverem corretas, e pela numeração das casas de José, acreditamos que o arrolamento das casas iniciou-se na banda oeste do mesmo pátio, mas não imediatamente "ao pé" da lgreja Matriz - como se dizia na época. A Figura 3 mostra onde provavelmente se iniciou o levantamento das casas dos logradouros, e a localização das casas do alferes José. E seguiu de modo que a casa arrolada em seguida fosse a mais próxima, e assim sucessivamente, até reencontrar a Matriz, no final do percurso, fechando o circuito.

Arbitrado o sentido dos logradouros, o passo seguinte foi determinar os lados. Como já dito, diferentemente das outras vilas pesquisadas, em Curitiba - livro de Décima não menciona os lados (direito e esquerdo) da posição das casas nos logradouros. Questionamos, portanto, qual a lógica do arrolamento das casas pelo escrivão.

Pelos vestígios documentais recolhidos, acreditamos que teriam sido inventariadas as casas de um lado, depois as do outro, contudo sem o cuidado de anotar o momento da mudança de lado. Comparando as escrituras de compra com a Décima, tivemos ciência de que as casas arroladas sequencialmente nessa segunda fonte histórica eram, de fato, vizinhas. Conforme livro de notas do tabelião, em 1802, no beco de São Francisco de Paula, eram proprietários: Gertrudes Ribas; o guarda-mor Joaquim Mariano Ribeiro Ribas; e Antonio de
93. Tabelinato ( n. 30, 1808, f. 65-66).

94. Cf. Décima urbana de Curitiba (f. 158 r. e v.)

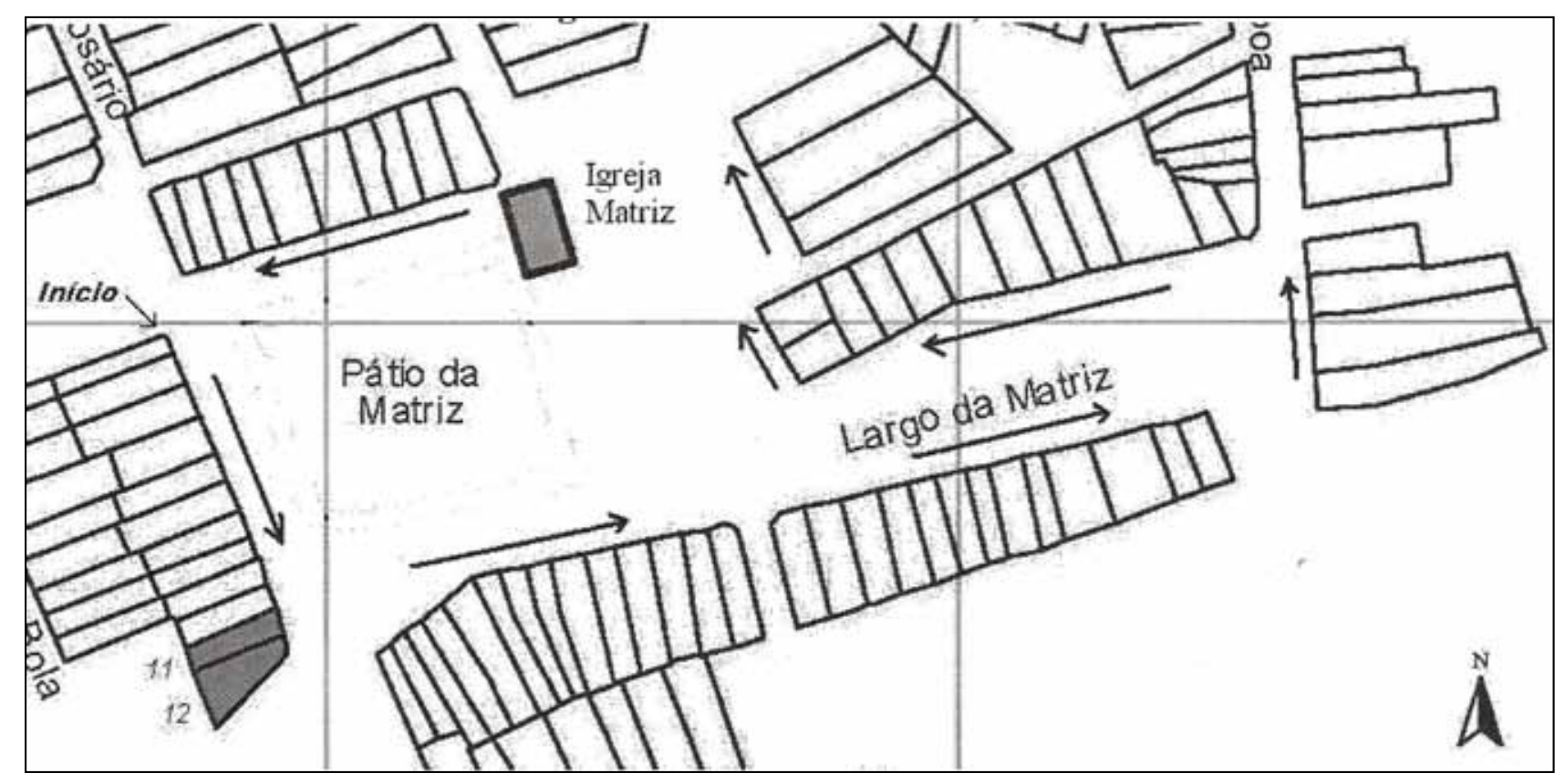

Figura 3 - Início e direção hipotéticos do arrolamento, na Décima, do pátio e largo da Matriz de Curitiba, 1810. 
95. Tabelionato (n. 27, 1802, f. 48 r. e v.)

96. Talvez com exceção de Joaquim Mariano Ribeiro Ribas, que era chefe, pois sua irmã Maria Ribas teria lhe vendido a casa em 1802, mas a negociação parece não ter sido concluída. Casas numeradas 10,11 e 12 na Décima de Curitiba. Cf. Décima urbana de Curitiba (f. 169r. e v).

97. Tabelionato (n. 32, 1811, f. 14r.-15v.)

98. Tabelionato (n. 31, 1809 , f. 22r.-23v.)

99. Tabelionato (n. 30, 1808, f. $74 \mathrm{v} .-75 \mathrm{r}$ )
Souza Leal95. Oito anos depois, na Décima, os mesmos vizinhos foram sequencialmente arrolados na rua do Jogo da Bola (novo nome do beco), nas casas 1 1, 12 e 1396. Em outros casos em que havia dois vizinhos, localizamos sequências semelhantes na rua Nova das Flores e na do Rosário. Demonstrando assim que, provavelmente, apesar do descuido do escrivão, pelo menos no pátio e largo da Matriz as casas foram arroladas pelos vizinhos de fachada, um após o outro. A confirmação parcial dessa hipótese levou à sua generalização para todos os logradouros.

A etapa seguinte foi conhecer por qual lado (esquerdo e direito) teria iniciado o arrolamento dos imóveis, pois isso ajuda a compreender a lógica do escrivão no registro das casas. De acordo com a planta de 1857, a rua do Fogo e a Fechada eram ocupadas em ambos os lados. O início pelo lado esquerdo foi nossa primeira hipótese, baseados em uma escritura de compra. Em 1811 , Francisco Teixeira Alves (proprietário de um imóvel presente na Décima) vendeu sua casa na rua Fechada, fundos para a rua do Rosário. A suposição de que o arrolamento no imposto deve ter iniciado pelo lado esquerdo foi para que esse imóvel, de número cinco na Décima, pudesse ter fundos para a rua do Rosário ${ }^{97}$.

O escrivão da Décima de Curitiba arrolou, provavelmente, primeiro as casas do lado direito das seguintes ruas: do Jogo da Bola, Nova da Entrada, da Carioca de Cima, do Lisboa, do Rosário, e Nova das Flores. Em 1809, o capitão Inácio de Sá Sottomaior vendia sua casa na rua do Rosário, no canto para o beco que sai para o campo ${ }^{98}$. Na Décima, essa era a casa 16. A contagem deve ter-se iniciado, portanto, do lado direito, para que o campo ficasse do lado esquerdo (nos fundos, do lado direito, estava a rua Fechada).

Em 1808, o capitão Rodrigo Francisco Xavier Felix de Meira e Castro comprou uma casa na rua Nova das Flores indo para a "carioca", e em 1810 - na Décima - essa era a casa número 2, e os vizinhos proprietários não haviam mudado 99 . Para que fosse "canto" para a "carioca", a casa provavelmente estava localizada no lado direito da rua, que era o mais próximo da fonte de água. No sentido oposto, estava a travessa para o pátio da Matriz.

A sequência do arrolamento das casas da rua Nova da Entrada deve ter iniciado também pelo lado direito, para que haja consonância com a planta de 1857 e com a maquete de 1876, que indicam haver casas mais próximas da ponte (o provável início da rua) do que as do lado esquerdo.

Para alguns logradouros não foi possível identificar lados, tendo sido arbitrados como de único lado: ruas de São Francisco de Paula, de Nossa Senhora do Terço (ambas continuam até hoje com lado único), da Carioca de Baixo e o pátio e largo da Matriz. Observando as plantas do século XIX, para os logradouros ligados a igrejas foi definido o lado direito, e, para a rua Carioca de Baixo, o lado esquerdo. Essa escolha não prejudicou nossa análise. Devido ao baixo número de imóveis e, consequentemente, de habitantes, um eventual erro não distorce nossas conclusões. Faz pouca diferença (ou nenhuma) se dois imóveis estavam em um lado da rua, e outros três no outro, ou se os cinco estavam no mesmo lado. 


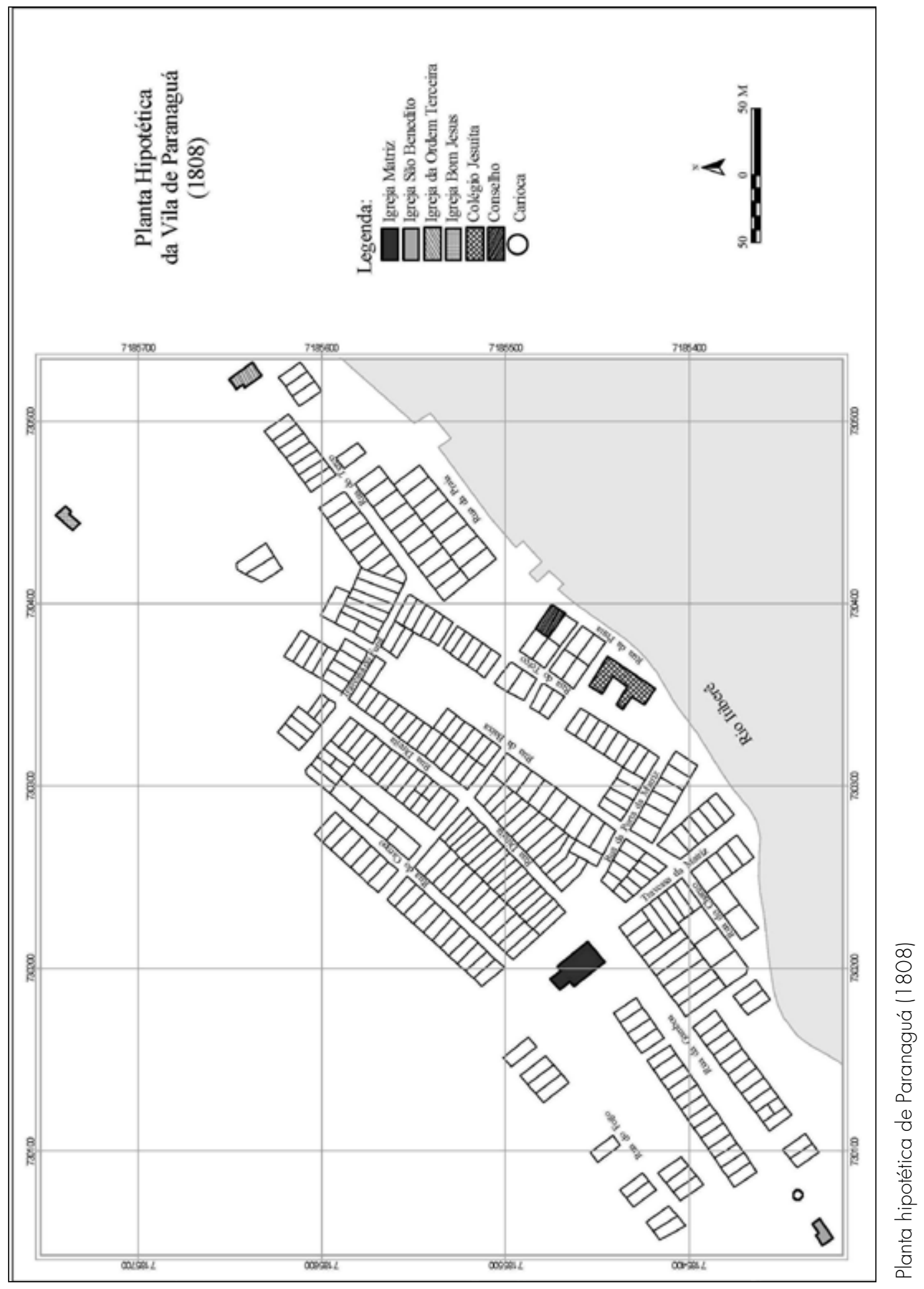




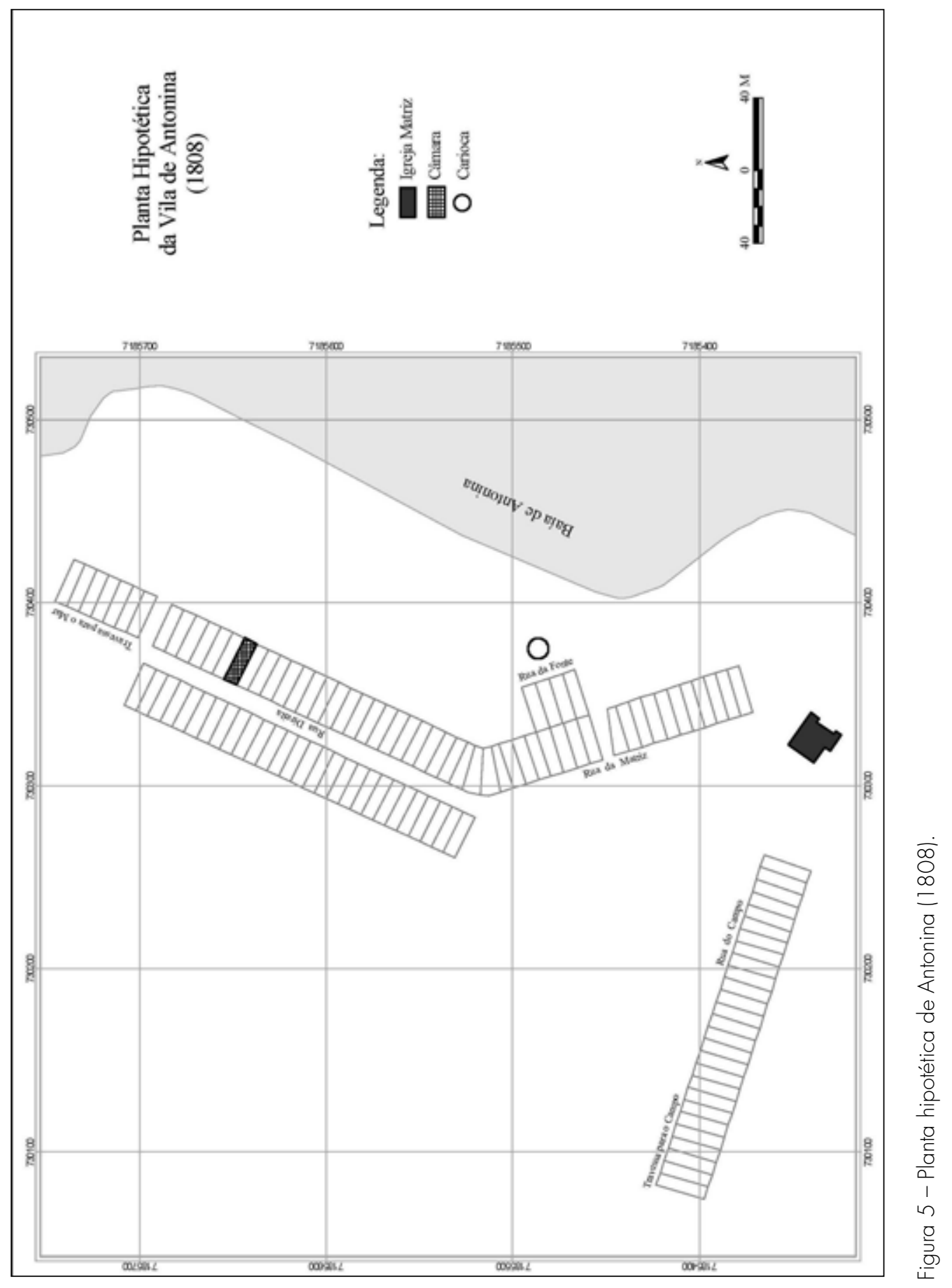




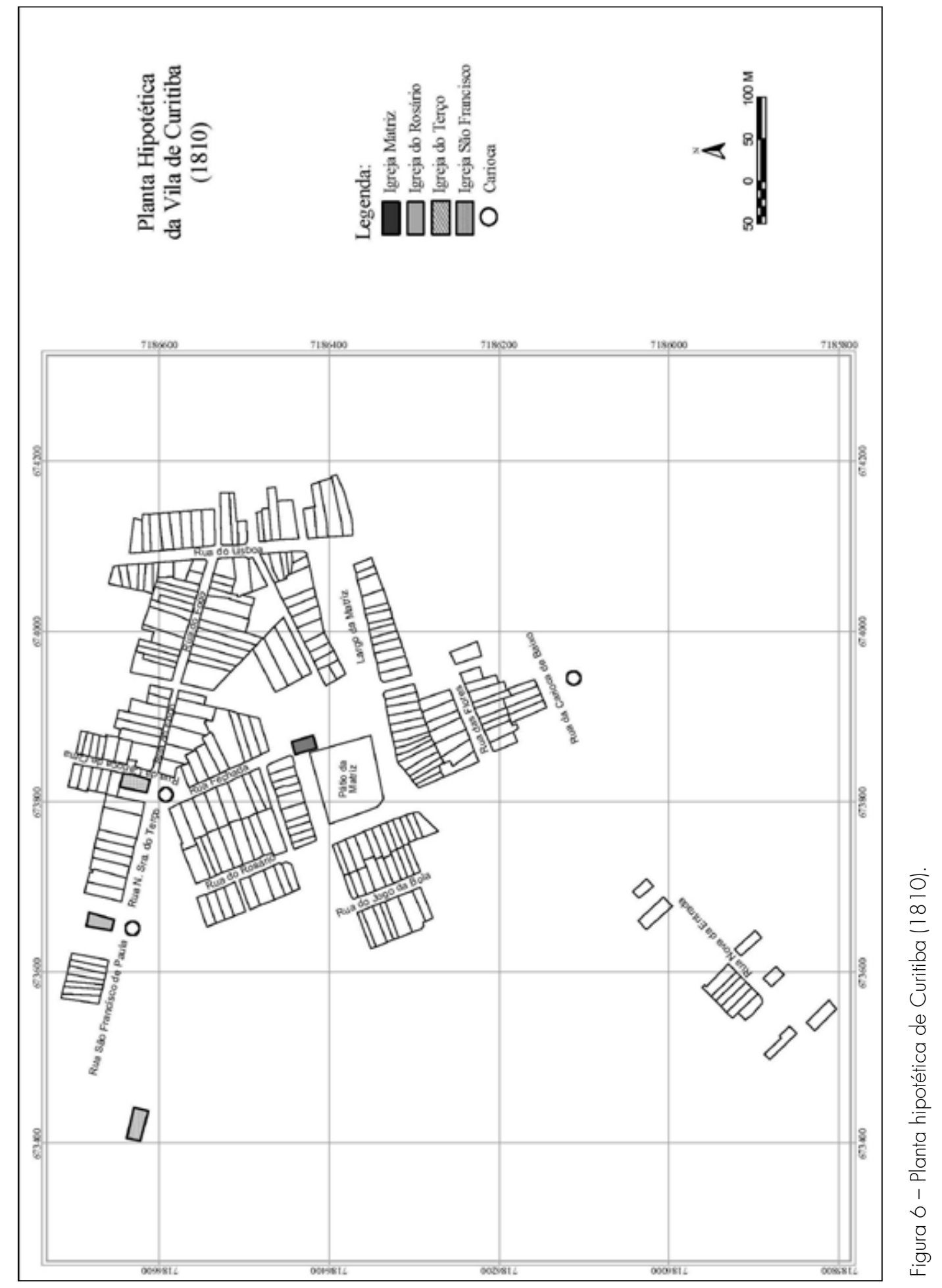


Escolhida a planta base e localizados os acidentes da topografia urbana, pudemos estabelecer as hipóteses de trabalho, que permitiram relacionar aproximadamente cada habitante ao lote em que morava. A apresentação desta etapa não encerra a descrição do nosso processo metodológico. A Décima, fosse de Paranaguá, Antonina ou Curitiba, não trazia dados suficientes para nossa análise socioeconômica, por não qualificar os chefes de domicílio registrados. Foi necessário buscar outras fontes que melhor caracterizassem tais moradores: a fase final da metodologia.

Os livros de Décima relacionam apenas os nomes dos proprietários e inquilinos das casas. Como em outras fontes, às vezes também era indicada a patente, na milícia, ou os cargos auxiliares. Para as mulheres com maior distinção social, utilizavam o tratamento "Dona". Nenhum outro elemento que caracterizasse socialmente os moradores do setor citadino foi registrado. Como esse trabalho tem por objeto a análise da lógica da organização social refletida no espaço, foi necessário caracterizar melhor os chefes de domicílio.

As Listas Nominativas de Habitantes serviram para essa tarefa. Trata-se de censos nominativos em que a população da vila foi arrolada domicílio a domicílio. Nelas aparecem os núcleos domiciliares e, na sequência, estão registrados alguns dados sobre as pessoas: idade, estado conjugal e cor social. Títulos da patente miliciana ou dos cargos auxiliares também eram citados, assim como o modo de sustento da casa: vive de sua fazenda, tem um botequim, oficial de sapateiro etc. Tal fonte existe para todas as vilas analisadas. Buscávamos, principalmente, ocupações, cor social, origem, e número de escravos dos chefes.

Tais listas foram produzidas principalmente entre as décadas de 1760 e de 1830. Escolhemos trabalhar com aquelas da primeira década do século XIX. A necessidade de usar esse conjunto de listas se deve ao desencontro das informações. Nas Décimas, existem chefes com domicílios urbanos, e proprietáriosmoradores que foram inventariados como aí morando, mas que, por algum motivo, no ano do imposto, não constam nas Listas Nominativas das vilas pesquisadas (aproximadamente $20 \%$ em cada vila).

Mesmo com o extenso quadro produzido através das Listas Nominativas, decidimos avançar ainda mais. Nas três vilas analisadas, para melhor recompor a situação social dos chefes de domicílio, voltamo-nos para os livros das Câmaras e os das Irmandades. Isto para saber quem integrou essas instituições e, assim, ter indícios do prestígio social deles.

Mas não resistiu ao tempo o livro do período colonial da Câmara de Paranaguá, nem aquele de Antonina. Nessas vilas nos valemos de meios indiretos para conhecermos os oficiais do Concelho - basicamente pesquisas feitas por historiadores do passado, como Antonio Vieira dos Santos e Ermelino de Leão. Já em Curitiba, houve grande cuidado na preservação dessa documentação, tendo, 
inclusive, sido publicadas transcrições das atas de Câmara, no século XX, organizadas pelo memorialista Francisco Negrão.

Além dos cargos maiores (vereador, juiz-ordinário e procuradortesoureiro), pudemos conhecer quem exerceu os cargos menores da administração municipal de Curitiba. Nos livros dos almotacés da vila, procuramos os chefes de família que ocuparam funções de porteiro, alcaide e almotacé - postos de execução, sem poder de decisão. Também com essas duas fontes citadas (livros da Câmara e os dos almotacés), conhecemos os nomes dos escrivães da Câmara, da almotaçaria, e os do juízo de órfãos. Já os dos tabeliães foram obtidos através dos livros notoriais.

$\bigcirc$ pertencimento a irmandades era outro elemento a nos dar indício da condição social do morador. Até onde sabemos, não eram muitas as irmandades das elites na região sul da capitania de São Paulo. A cor social era, provavelmente, o principal elemento definidor da entrada nas confrarias. Outro motivo de agregação eram as ocupações. No atual estado do Paraná, no entanto, parece não ter havido irmandades profissionais (de sapateiros, comerciantes, fazendeiros etc.). Não há estudos a respeito e, tampouco, fontes conhecidas. Para Curitiba e Paranaguá, tivemos acesso às transcrições dos livros de irmandades brancas; para Antonina, não encontramos qualquer material ${ }^{100}$.

Além de relacionar os confrades e os agentes camarários, agregamos à análise os eleitores de Curitiba. No Brasil, a eleição dos ocupantes desses cargos era feita através de voto indireto. $O$ povo "qualificado" lentenda-se branco e com prestigiol votava em um grupo de eleitores que, por sua vez, elegia os ocupantes da Câmara. Os livros de eleições da Câmara serviram a esta tarefa, que também foi auxiliada pelas tabelas de Fernando Cunha, outro historiador ${ }^{101}$.

Por fim, para a análise da distribuição dos chefes, há outro elemento social relevante: a origem. Em regra, nas Listas Nominativas de Antonina e de Paranaguá, anotava-se a naturalidade dos moradores. Em Curitiba, a informação não era registrada, com exceção da Lista de 1801 e da de 1806, quando alguns chefes tiveram sua origem anotada. Para suprir tal dificuldade, valemo-nos das atas de casamento (que, às vezes, indicam a origem dos noivos) e da genealogia elaborada por Francisco Negrão ${ }^{102}$. No entanto, apesar de todo esse esforço, na atribuição do local de nascimento aos chefes de família arrolados na Décima de Curitiba, só tivemos êxito para 36,5\% dos chefes, que, por ser porcentagem muito restrita, praticamente inviabiliza qualquer conclusão quanto à escolha do local de moradia pela variável da origem. Em outras análises - por exemplo, na composição da nobreza da terra -, essa variável, porém, não foi descartada.

Esperamos assim ter conseguido - de modo parcial, é claro - recompor com mais precisão o estatuto social dos moradores de Paranaguá, Antonina e Curitiba, tendo em vista compreender se alguma variável socioeconômica explica uma possível setorização no espaço urbano daquelas vilas (como Elias e Scotson pensaram sobre Winston Parva ${ }^{103}$ ); ou, o que é mais provável, se um conjunto de dados esclarece os motivos da distribuição socioespacial (como S. Gomes ponderou para Antonina ${ }^{104}$.
100. Ver Nely L. V. Almeida (1975); e Antonio Vieira dos Santos (2001, v. 2, p. 55-71).

101. Cf. Fernando Cunha (2003, p. 72-77).

102. Curitiba. Livros de atas de casamento n. 3 e 4 (17801810). Acervo da Catedral Basílica Menor de Curitiba. Cópia digital do Cedope/ Dehis-UFPR.

103.Ver Norbert Elias e John L. Scotson (2000).

104. Ver Sandro V. Gomes (2004). 
105. Cf. Beatriz P. S. Bueno (2005, p. 73-75).

106. Cf. Sandro V. Gomes (2004, p. 28-31).
Aplicação do método

No início deste artigo nos perguntamos se havia algum padrão espacial na constituição de vizinhanças nas vilas analisadas. Partimos da hipótese de que as pessoas tinham tendência a habitar próximas aos seus iguais. A historiografia tem mostrado que, na Metrópole, existiam segmentações urbanas (ruas, áreas ou bairros) onde se concentravam comerciantes, artesãos, pobres ou ricos. Também no Brasil essas concentrações pareciam ocorrer. Nossa análise identificou que, em Paranaguá, Antonina e Curitiba, no início do século XIX, havia uma diferenciação socioespacial, cujos contornos, porém, eram menos evidentes.

$\mathrm{Na}$ maior parte das vilas e cidades de matriz portuguesa, aparentemente não havia espaços tão especializados quanto os das ruas de profissões de Lisboa ou do Porto. É óbvio que, devido às suas dimensões acanhadas, as vilas estudadas não poderiam comportar tal nível de segmentação. No entanto, foi possível, mesmo assim, perceber que o espaço ocupado não era homogêneo nem indiferenciado. Os moradores pareciam procurar se distinguir, também, através do espaço de habitação, gerando certo zoneamento. Nas três vilas analisadas, o recorte espacial mais evidente era a existência de regiões onde se concentravam as elites locais. Em contrapartida, havia regiões onde se concentravam os de poucas posses.

O estudo da Curitiba do início do século XIX permitiu perceber que se pode considerar área preferencial de moradia da maior parte dos principais da vila a região que fica a norte e a oeste da lgreja Matriz - principalmente a daquelas moradias mais próximas a esse prédio. Ficava na parte mais elevada da área urbana e era a mais cuidada pela Câmara: aí, várias vezes no ano, eram refeitos os calçamentos e regos (canais para escoar a água), e tornaram-se espaços privilegiados de habitação da elite as ruas Fechada e do Rosário, e parte do Pátio da Matriz. Nessa região concentravam-se as casas de mais alto valor, moradias dos chefes com os postos elevados na milícia, e dos que exerceram os principais cargos da Câmara. $\bigcirc$ fenômeno parece ser generalizado-igrejas, em especial as matrizes, eram polos de valorização espacial. $\bigcirc$ que, por outra via, demonstra a importância desse tipo de acidente da topografia urbana no imaginário de seus moradores ${ }^{105}$.

A elite antoninense tinha, também, seu espaço preferencial nas proximidades da lgreja Matriz. Os moradores de elevada condição social (camarários, patentes mais elevadas, donos de escravos etc.) residiam quase exclusivamente nas ruas da Matriz e Direita, situadas a leste da igreja. Como em Curitiba, esses logradouros de Antonina situavam-se em área elevada e mais próxima à principal igreja da vila. Eram onde se localizavam as casas mais caras, onde habitavam os principais comerciantes e agricultores da vila ${ }^{106}$.

Em Paranaguá, a situação era um pouco diferente: a única vila em que foi possível identificar a presença de duas elites, uma comercial e outra rural, que tinham espaços relativamente distintos de moradia urbana. A elite mercantil 
habitava, sobretudo, nas ruas do Terço e da Praia. Eram logradouros onde se concentrava a maioria dos negociantes, e boa parte dos armazéns da vila. Esses chefes tinham posições elevadas na milícia e nas ordenanças, como as de capitães. Aí se concentravam os que exerceram cargos camarários e os confrades das duas principais irmandades brancas. Seus habitantes formavam parte significativa da elite socioeconômica local, com status social já enraizado e elevado.

Já a elite agrária parnanguara optou por morar, principalmente, na rua Direita - nome de logradouro que, em outras cidades luso-brasileiras, a historiografia nacional tem ligado a ruas de comércio. Os fazendeiros de Paranaguá não eram os detentores das posições mais elevadas na estrutura social. Assim, apesar de constituírem grande força social, os moradores da rua Direita tinham posições mais baixas do que os da rua do Terço. Em geral, suas posições estavam abaixo das dos negociantes, fossem na milícia, nos cargos na Câmara, ou no pertencimento às irmandades, entre outras variáveis. Quanto ao número de escravos, porém, os moradores da Direita eram, em média, donos dos maiores plantéis, provavelmente porque as atividades ligadas à terra exigiam mais braços; e, caso se mantivessem restritos aos negócios mercantis, os negociantes geralmente não tinham tal necessidade.

Enquanto a elite de Antonina morava quase toda nos logradouros mais próximos ao mar, as opções em Paranaguá eram diversas - pois, como vimos no caso dos comerciantes, tinham, possivelmente, motivo funcional (estavam mais próximos do porto). Nossas demonstrações indicaram que, em Antonina, não havia grande diferença de moradia entre agricultores e comerciantes de maior porte. A pequenez da vila possivelmente, não permitia essa distinção espacial por atividade econômica. Também, não fomos capazes de perceber se havia diferenças entre a elite que morava na rua Direita e a dos moradores da Matriz.

Talvez por ter sido, no século XVIII, a maior vila do sul de São Paulo em importância econômica e efetivo populacional, em Paranaguá a diferença entre esses dois grupos profissionais era mais evidente. Tais escolhas puderam ser, na medida do possível, explicadas, principalmente, por fatores econômicos, mas também por certas necessidades de ordem prática. Negociantes voltavam-se para o mar por dele depender a chegada de seus produtos; os fazendeiros, para a zona rural, de onde tiravam seu sustento.

Os "pobres" das três vilas pesquisadas também tinham suas áreas de habitação urbana, que, em geral, estavam em locais mais baixos e alagadiços (portanto, insalubres). Em Curitiba, os moradores de baixa condição social habitavam, grosso modo, a região ao sul e ao leste (da lgreja Matriz), que sofria com alagamentos e com a falta de cuidados da Câmara ${ }^{107}$. Foi uma área que se desenvolveu em oposição àquela ocupada pele nobreza da terra. Talvez essa distância relativa (já que as casas estavam separadas pelo pátio da Matriz) fosse justamente para criar tal diferença. Pelo pequeno tamanho do setor urbano, não havia um bairro urbano específico para cada um desses grupos, mas áreas "seletivas". Em geral, os chefes pobres da região sul-leste não tinham patentes na
107. O setor urbano de Curitiba (do início do XIX) localiza-se na parte mais baixa de um planalto. Como era uma região que convivia com as chuvas, principalmente no verão, os alagamentos eram constantes. A abertura de regos e o calçamento eram medidas paliativas recorrentes na área dos nobres, porém na região dos pobres isso não acontecia. É o que se pode supor com o auxilio dos Livros de audiências e correições dos almotacés. 
108. Cf. Sandro V. Gomes, (2004, p. 32). milícia, nem cargos na Câmara - nem mesmo cargos menores. Não eram confrades da principal irmandade branca da vila tampouco proprietários de escravos. Mas não eram socialmente desqualificados: nas Listas Nominativas sua qualificação era "pobres".

Em Antonina, a localização das camadas mais despossuídas era semelhante à que ocorria em Curitiba: opunha-se à da elite. $\bigcirc$ distanciamento aí era, inclusive, espacialmente mais marcado ${ }^{108}$. Do modo como imaginamos o setor citadino antoninense no início do século XIX, os logradouros do Campo não eram paralelos aos da Praia. Se a elite local agrária e comercial (detentora dos mais elevados títulos milicianos, cargos da Câmara, escravos, etc.) morava, sobretudo, nos logradouros próximos ao mar, os pobres (que estavam alijados de qualquer distinção social) habitavam, principalmente, nas ruas do Campo. É possível imaginar que essa distância marcava com traços mais fortes essa diferença.

Já em Paranaguá a situação era diferente. Se entre as elites havia uma relativa dispersão (em dois logradouros não paralelos), entre os pobres percebeuse uma pulverização maior. Habitavam, principalmente, os logradouros das bordas da vila: a rua do "Chargo" e a do Fogo; e também na travessa do Funil, assim como na rua da Baixa (que sofria com alagamentos), no centro da vila. Os preços das casas não eram ditados pela maior ou menor distância da lgreja Matriz, porém, em muitos casos, estavam nessas ruas as residências dos chefes de domicílios mais pobres, que tinham ocupações pouco lucrativas.

Havia, ainda, os que não eram nem pobres nem nobres: geralmente moradores com algum cabedal, porém com pouca, ou baixa, distinção social. Em Curitiba, não se pode falar que o taberneiro João da Costa Silva, com dez escravos, fosse alguém financeiramente pobre, mas também não integrava a nobreza da terra. Provavelmente, não tinha alcançado distinção suficiente para ser considerado um negociante pela elite comercial do lugar (nem, portanto, igual a eles). Era um pequeno comerciante que estava enriquecendo, mas que ainda tinha alguns passos a dar rumo ao topo da estrutura social local. Essa situação é sugerida por sua baixa patente miliciana, por não integrar a principal Irmandade da vila, mas já ter sido almotacé - porta de entrada para os principais cargos do Concelho.

Ainda em Curitiba, outros homens com alguma riqueza - porém sem grande posição social - moravam na rua do Jogo da Bola, à oeste da Matriz, e na de Nossa Senhora do Terço, a nordeste do mesmo referencial. Talvez porque, não por acaso, esses dois logradouros estavam muito próximos da área ocupada pela nobreza da vila. A rua do Jogo da Bola era paralela ao pátio; iá a rua do Terço estava conectada por um largo à rua do Rosário. Com o "enobrecimento" desses chefes, a região nordeste continuaria a concentrar a elite local.

Em Paranaguá, os intermediários entre pobres e nobres eram um pouco mais ricos (em média, mais escravos e propriedades urbanas) do que os já citados. Localizavam-se, principalmente, na rua da Gamboa (do lado esquerdo da Matriz) e na travessa da Matriz (ao pé da mesma igreja). Eram moradores de 
boa condição econômica, porém de posição social mediana, iá que tinham funções menores na milícia (ou eram padres) e, geralmente, não tinham exercido cargos na Câmara. Ainda não aliavam status econômico e social. Caso alcançassem graus mais elevados na hierarquia social, a localização geral dos nobres e pobres continuaria do mesmo modo: espalhados por todo o setor urbano, mas com as concentrações referidas.

No caso de Antonina, isso não pôde ser verificado. As dificuldades de se atribuir diferenças entre agricultores e comerciantes (quem era pequeno ou grande) foram um obstáculo para esmiuçarmos melhor os diferentes tipos sociais ali residentes. A distância entre o que era ser pobre ou ser rico devia ser muito pequena e, provavelmente, não era isso que determinava as diferenças. Ou, talvez, em vilas menores a polarização fosse mais acentuada, por isso a falha em identificar e localizar um "grupo" médio.

Portanto, nas três cidades analisadas, podem-se perceber espaços diferenciados para moradores distintos socialmente. No período colonial, parte do processo de seleção de vizinhos pode ter tido como instrumento a obrigação legal de construir a casa em até um ano após receber o lote urbano. Essa barreira era sutil, porém bastante eficaz, pois impedia que a maior parte da população pudesse morar no setor citadino, por não ter meios para edificar em prazo tão curto. Entre aqueles que de algum modo podiam morar em uma casa urbana (fosse de aluguel, por aquisição ou doação etc.), em geral os logradouros acessíveis, como mostramos, não eram os mesmos. Pobres viviam em áreas alagadas, enquanto os mais abastados tinham suas casas em setores mais elevados, com boa infraestrutura. E esse foi um modo indireto de compreender como os lotes urbanos se distribuíam: não mais dispomos das cartas de datas para qualquer uma das vilas examinadas.

Em Curitiba, a partir de 1829 - e posteriormente nas demais cidades "paranaenses" (Castro, Guarapuava, Ponta Grossa etc.) -, as medidas explícitas adotadas pelas Câmaras na tentativa de expulsar os pobres da área urbana são mais conhecidas. O historiador Magnus Pereira demonstrou como esse processo ocorreu ${ }^{109}$. Em 1829, nas principais ruas da vila, a Câmara de Curitiba proibiu choupanas de pau a pique cobertas de palha. Esse modo de edificar era visto como próprio de áreas mais periféricas, portanto não compatíveis com as ruas e travessas onde moravam os homens-bons. Tal restrição seria estendida, em 1836, para todas as casas citadinas de Curitiba.

Para os vereadores, nesses logradouros (e mais tarde em toda a vila) deveria haver somente casas de pedra e cal, cobertas de telhas. Casas de taipa de pilão ou de estuque - que eram modos construtivos mais elaborados do que o de pau a pique e palha - também eram aceitas como moradias das ruas principais. Em Paranaguá, esse ideal já tinha sido alcançado, haja vista a notícia, dada por Saint-Hilaire em 1820 - provavelmente com certo exagero -, de que todas as casas urbanas eram do material mais nobre: pedra e cal. $\bigcirc$ que, em parte, explica os preços médios (e absolutos, também) dos imóveis nas três vilas
109. Cf. Magnus R. de M. Pereira, (1996, p. 116-124) 
110. Idem, 1996, p. 118.

111. Cf. Magnus R. de M. Pereira e Norton F. Nicolazzi Junior (2003, p. 68-69). analisadas: mais elevados em Paranaguá, eles eram 1,8 vezes superiores aos de Curitiba; e 3,7 vezes mais altos do que os de Antonina.

Com essas proibições, o preço das construções se elevaria. Isso, certamente, "selecionaria" a vizinhança ${ }^{10}$, restringindo ainda mais a possibilidade de moradores mais pobres residirem no setor urbano, pois legalmente não era permitido negar um lote a quem o requisitasse ${ }^{11}$. Outras medidas legais de seleção dos vizinhos vieram depois, como a definição, em 1836, de um limite mínimo para altura das casas - 18 palmos, ou 4 metros (que depois foi alterado para 20 palmos); e, no ano seguinte, para o tamanho das janelas e portas. Foram medidas impostas a quem quisesse construir ou reformar, o que pode indicar o tipo de morador que se desejava ter no setor citadino, isto é, os que tinham dinheiro.

Em Curitiba, ou em qualquer outra cidade luso-brasileira, impor um modo de construção era um dos modos utilizados para excluir dos setores urbanos moradores menos abastados. Havia, entretanto, outros meios de exclusão que não conseguimos identificar, mas foi possível perceber que, por menor que fosse a vila, a exclusão existia. $\bigcirc$ inexpressivo número de chefes não-brancos em Curitiba pode ser apontado como indicativo dessa situação. Parece que o morador pardo ou o negro não podia habitar no setor urbano da vila. $\bigcirc$ preço das casas, ou mesmo seu aluguel, pode ser apontado como um desses meios de "selecionar" moradores.

Considerações finais

Explicitamos aqui as três fases do processo: escolher uma planta-base; localizar os topônimos arrolados no livro de Décima, assim como suas direções e lados, esquerdo e direito; e, por fim, classificar os moradores arrolados nessa mesma fonte. Esta era a novidade do nosso trabalho: demonstrar nossa metodologia de reconstituição do loteamento e arruamento urbanos em Paranaguá, Antonina e Curitiba no início do século XIX.

A aplicação foi uma consequência. Partimos da hipótese de que moradores citadinos formavam vizinhanças com pessoas de semelhante condição social. Isso conseguimos demonstrar - principalmente entre os mais abastados las elites), que escolhiam seus locais de moradia. E ainda mais: que nas entrelinhas das posturas municipais havia um processo de exclusão dos "pobres". Para ser nobre, provavelmente, um dos "requisitos" era ter uma casa na cidade - afinal, porque gastar dinheiro mantendo um imóvel citadino se não se reside nele? A resposta a essa pergunta (retórica, confessamos) é: para manter as sociabilidades. Afinal a cidade era o palco onde se revelavam as disputas - entre as elites ou no interior delas. 


\section{REFERÊNCIAS}

FONTES

Jornal Dezenove de Dezembro. Curitiba, mar. 1855- mar. 1857, edição fac-similar, v. 2, 1980, v.3, 1981.

\section{Documentos públicos e livros}

ANDRADA, Martim Francisco R. de. Jornal de viagem por diferentes vilas desde Sorocaba até Curitiba, principiada a 27 de novembro de 1802. Revista do Instituto Histórico e Geográfico Brasileiro, Rio de Janeiro, v. 45, 1882 (parte 1).

BRASIL. Collecção das Leis do Brazil de 1808. Rio de Janeiro: Imprensa Nacional, 1891a.

BRASIL. Collecção das Leis do Brazil de 1809. Rio de Janeiro: Imprensa Nacional, 1891b.

CURITIBA. Boletim do Arquivo Municipal de Curitiba, Curitiba, v. 18, 1925; v. 27,1927; v. 33, $1927 ;$ v. 47, 1930 v. 52, 1931.

TABELIONATO de Curitiba. Livros de Notas dos Tabeliães. n.27, 1802; n. 30, 1808;n. 31, 1810;n. 32, $1811 ;$ n. 33, 1818. Acervo do Primeiro Tabelionato de Notas de Curitiba. Cópia digital do Cedope/ Dehis, UFPR.

Curitiba. Livros de atas de casamento n. 3 e 4 (1780-1810). Acervo da Catedral Basílica Menor de Curitiba. Cópia digital do Cedope/ Dehis-UFPR.

DÉCIMA urbana de Antonina. In: Livro de Lançamento do imposto de dízimos de Paranaguá (10 nov.1808 a 6 fev.1857), códice IM V.1.Acervo do Arquivo da Biblioteca da Câmara Municipal de Curitiba.

DÉCIMA urbana de Curitiba. In: Livro de Lançamento de dízimo (predial) de Curityba, códice IM V.2, f. 139 r-178 v.Acervo do Arquivo da Biblioteca da Câmara Municipal de Curitiba.

DÉCIMA urbana de Paranaguá. In: Livro de Lançamento do imposto de dízimos de Paranaguá (10 nov.1808 a 6 fev.1857), códice IM V.1. Acervo do Arquivo da Biblioteca da Câmara Municipal de Curitiba.

PEREIRA, Magnus R. de M.; NICOLAZZI JUNIOR, Norton F. (Org.). Audiências e correições dos almotacés (1737 a 1828). Curitiba:Aos Quatro Ventos, 2003.

SAINT-HILAIRE,Auguste. Viagem pela comarca de Curitiba. Curitiba: Fundação Cultural, 1995.

SANTOS,Antonio César de A. (Org.). Provimentos da Vila de Paranaguá (1721). Monumenta, Curitiba, v. 3, n. 10, p. 81-174, 2000.

SANTOS, Antonio Vieira dos. Memória bistórica de Paranaguá (1850). Curitiba:Vicentina, 2001. $2 v$.

WESTPHALEN, C. Uma cidade portuária nos meados do século XIX. Separata de: SIMPÓSIO NACIONAL DOS PROFESSORES UNIVERSITÁRIOS DE HISTÓRIA:A Cidade e a História, 7., v. 2, 2-3 set. 1973, Belo Horizonte. Anais... São Paulo: SBPH, 1974. p. 537-550. 
PARANAGUÁ. 4ª Companhia de Ordenanças. Lista Nominativa de habitantes de Paranaguá (1767). Códice 2105. Transcrição Julia Maria Ribeiro.Arquivo Digital. Projeto Resgate, São Paulo.

PARANAGUÁ. Lista nominativa de habitantes de Paranaguá (1772), f. 8 [paginação 186, do arquivo digital]. Resgate, São Paulo, códice 2105.

\section{LIVROS, ARTIGOS E TESES}

ALMEIDA, Nely L.V. Curiosidades Históricas da Irmandade de Nossa Senbora da Luz dos Pinhais de Curitiba. Curitiba: Edição da autora, 1975.

ALVAREZ, Antônio. Os novos aspectos de Paranaguá. A rua thermometro. Maus tempos. Volta ao progresso. Gazeta do Povo, Curitiba, 25 de fev. 1928, ano 10, n. 2779, p. 1. [ocupa a página 1 somente]

BANDEIRA, Miguel S. de Mello. O espaço urbano de Braga em meados do século XVIII: a reconstituição da cidade a partir do Mappa das Ruas de Braga e dos Índices dos Prazos das Casas do Cabido. Porto:Afrontamento, 2000.

BENATTI,Antônio P.; SUTIL, Marcelo S. Rui Barbosa: a praça na trilha do tempo. Boletim informativo da Casa Romário Martins, Curitiba, v. 23, n. 119, p. 1-24, 1996.

BERG, Claus Luiz. Antonina, a vovó do Paraná. Curitiba: Edição do autor, 2003.

BOSCHILIA, R. Cores da cidade: Riachuelo e Generoso Marques. Boletim Informativo da Casa Romário Martins, Curitiba, v. 23, n. 110, p. 79, 1996.

BOSCHILIA, Roseli.A rua 15 e o comércio do início do século. Boletim Informativo da Casa Romário Martins, Curitiba, v. 23, n. 113, p. 101-105, 1996.

BOUTIN, Leônidas. Histórias Paranaenses. Curitiba: Chain, 2003.

BUENO, Beatriz P. S. Tecido urbano e mercado imobiliário em São Paulo colonial: metodologia de estudo com base na Décima urbana de São Paulo em 1809. Anais do Museu Paulista, São Paulo, v. 13, n. 1, p. 59-97, jan.-jun. 2005.

CAROLlo, Cassiana L. Cemitério municipal São Francisco de Paula: monumento e documento. Boletim Informativo da Casa Romário Martins, Curitiba, v. 22, n. 104, p. 64, 1995.

CARRARA, Ângelo A. A Real Fazenda de Minas Gerais: guia de pesquisa da coleção Casa dos Contos de Ouro Preto, 1. Ouro Preto: Universidade Federal de Ouro Preto, 2003. Disponível em: <http://www.ufjf.br/hqg/files/2009/10/A-Real-Fazenda-I.pdf $>$.

CAVALCANTI, Nireu. O Rio de Janeiro setecentista: a vida e a construção da cidade, da invasão francesa até a chegada da Corte. Rio de Janeiro: Zahar, 2004.

CHMYZ, Igor (Coord.). Relatório final do Projeto para a constatação e resgate do patrimônio arqueológico na área das obras de revitalização da Praça Tiradentes, em Curitiba, Paraná. Curitiba: Centro de Estudos e Pesquisas Arqueológicas-UFPR, 2010.

CUNHA, Fernando. Elites políticas municipais no Brasil-colônia: homens-bons da Curitiba setecentista. 2003. Dissertação (Mestrado em História) - Universidade Federal do Paraná, Curitiba, 
2003. Disponível em: <http://dspace.c3sl.ufpr.br/dspace/bitstream/handle/1884/24824/D\%20-\%20CUNHA,\%20FERNANDO.pdf?sequence $=1>$.

DUDEQUE, Irã José T. Cidade sem véus: doenças, poder e desenhos urbanos. Curitiba: Champagnat, 1985.

ELIAS, Norbert; SCOTSON, J. L. Ensaio teórico sobre as relações estabelecidos-outsiders. In: Os estabelecidos e os outsiders: sociologia das relações de poder a partir de uma pequena comunidade.Trad.Vera Ribeiro. Rio de Janeiro: Zahar, 2000. p. 19-50.

FERREIRA, Maria da Conceição F. Elementos para um estudo sociotopográfico de Guimarães na baixa Idade Média: um espaço residencial de elite. Cadernos do Noroeste, Braga, v. 2, n. 2-3, p. 179$216,1989$.

FREITAS, Waldomiro F. História de Paranaguá: das origens à atualidade. Paranaguá: Instituto Histórico e Geográfico do Paraná, 1999.

GLEZER, Raquel. Chão de terra e outros ensaios sobre São Paulo. São Paulo:Alameda, 2007.

GOMES, Sandro V. Organização espacial numa vila colonial luso-brasileira, Antonina, 1808. Trabalho de conclusão de curso (Bacharelado em História) - Universidade Federal do Paraná, Curitiba, 2004. Disponível em <http://www.historia.ufpr.br/monografias/2003/sandro_vieira_gomes.pdf $>$.

HOUAISS, Antonio et al. Dicionário eletrônico Houaiss da língua portuguesa. Rio de Janeiro: Objetiva, 2007.

KATO, Allan Thomas T. Outra Paranaguá urbana: implicações socioeconômicas na configuração espacial de uma vila colonial (1808). Trabalho de conclusão de curso (Bacharelado em História) Universidade Federal do Paraná, Curitiba, 2004.

. O espaço urbano colonial reconstituído: notas de uma metodologia. In: SEBRIAN, Raphael N. N. et al. (Org.). Perspectivas bistoriográficas. Campinas: Pontes, 2010. p. 167-179.

Retrato urbano: estudo da distribuição socioespacial dos moradores de Paranaguá,Antonina e Curitiba no início do século XIX. 2011. Dissertação (Mestrado em História) - Universidade Federal do Paraná, Curitiba, 2011.

. Onde moravam os homens bons de Curitiba. In: CRUZ, Ana Lucia R. B. da; PEREIRA, Magnus Roberto M. (Org.). Curitiba e seus bomens-bons: espaço e sociedade na Vila de Nossa Senhora da Luz dos Pinhais. Curitiba: Fundação Cultural de Curitiba, 2011.p.10-31.

KOZAN, José M. Virtual beritage reconstruction: the Old Main Church of Curitiba, Brazil. 2004. Dissertação (Mestrado em Arquitetura) - University of Cincinatti, Cincinatti, 2004.

KUSHNIR, Beatriz. Traços da imigração portuguesa no acervo do Arquivo Geral da Cidade do Rio de Janeiro (parte I). População e Sociedade, Porto, n. 14-15, 2007.

LEÃO, Ermelino A. de. Contribuições históricas e geográficas para o Dicionário do Paraná. Curitiba: Instituto Histórico e Geográfico do Paraná, 1926. 2v.

Antonina: factos e homens. Da edade archeolithica à elevação à cidade - 1918 (1926).

Curitiba: Secretaria de Estado da Cultura, 1999.

Annals of Museu Paulista. v. 20. n.1. Jan.-Jun. 2012. 
MARTINS, Romário. Curityba de outr'ora e de boje. Curitiba: Prefeitura Municipal, 1922.

MARX, Murillo. Cidade Brasileira. São Paulo: Edusp; Melhoramentos, 1980. Nosso chão: do sagrado ao profano. São Paulo: Edusp, 2003.

PARANÁ. Boletim do Arquivo do Paraná, Curitiba, ano 6, n. 9, 1981.

PARANÁ. Pintores da paisagem paranaense. Curitiba: Solar do Barão-Secretaria de Estado da Cultura, 2001.

PEREIRA, Magnus Roberto de M. Cortesia, civilidade, urbanidade: conversando com Norbert Elias sobre a conformação do espaço e das sociabilidades na cidade medieval portuguesa. História: Questões \& Debates, Curitiba, v. 16, n. 30, p. 111-146, jan.-jun. 1999.

REIS FILHO, Nestor G. Imagens de vilas e cidades coloniais no Brasil. São Paulo: Edusp; Imprensa Oficial do Estado de São Paulo, 2001.

SILVA, Janice Th. São Paulo, 1554-1880: discurso ideológico e organização espacial. São Paulo: Moderna, 1984.

TREVISAN, Edilberto. O centro bistórico de Curitiba: sua formação, tentativa de localização de seus moradores (1668-1853). Curitiba: Chain, 1996. na, 2000 .

Curitiba na província: ruas, moradores antigos, explosão de cidadania. Curitiba:Vicenti-

WACHOWICZ, Ruy Christovam. As moradas da Senbora da Luz. Curitiba:Vicentina, 1993.

Curitiba: ruas, praças e becos. Revista da Academia Paranaense de Letras, Curitiba, v. 38, n. 62, p. 13-25, 1998. 